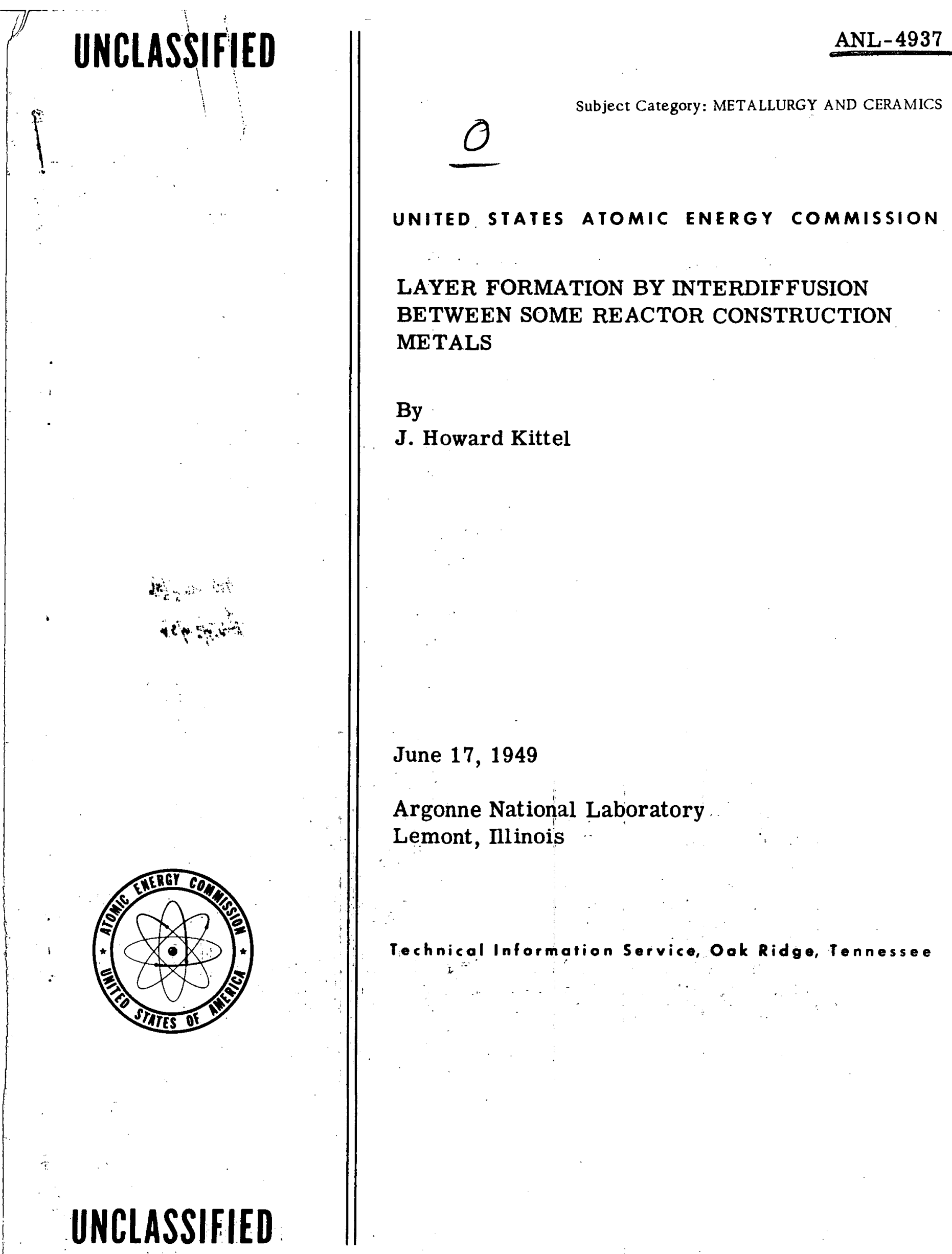




\section{DISCLAIMER}

This report was prepared as an account of work sponsored by an agency of the United States Government. Neither the United States Government nor any agency Thereof, nor any of their employees, makes any warranty, express or implied, or assumes any legal liability or responsibility for the accuracy, completeness, or usefulness of any information, apparatus, product, or process disclosed, or represents that its use would not infringe privately owned rights. Reference herein to any specific commercial product, process, or service by trade name, trademark, manufacturer, or otherwise does not necessarily constitute or imply its endorsement, recommendation, or favoring by the United States Government or any agency thereof. The views and opinions of authors expressed herein do not necessarily state or reflect those of the United States Government or any agency thereof. 


\section{DISCLAIMER}

Portions of this document may be illegible in electronic image products. Images are produced from the best available original document. 


\section{$-1$}

Date Declassified: December 9, 1955.

This report was prepared as a scientific account of Government-sponsored work. Neither the United States, nor the Commission, nor any person acting on behalf of the Commission makes any warranty or representation, express or implied, with respect to the accuracy, completeness, or usefulness of the information contained in this report, or that the use of any information, apparatus, method, or process disclosed in this report may not infringe privately owned rights. The Commission assumes no liability with respect to the use of, or from damages resulting from the use of, any information, apparatus, method, or process disclosed in this report.

This report has been reproduced directly from the best available copy.

Issuance of this document does not constitute authority for declassification of classified materlal of the same or similar content and title by the same authors.

Printed in USA, Price 25 cents. Available from the Office of Technical Services, Department of Commerce, Washington 25, D. C. 


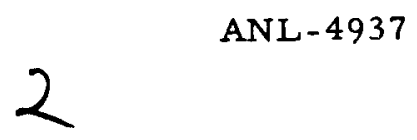

\author{
ARGONNE NATIONAL LABORATORY \\ P. O. Box 299 \\ Lemont, Illinois
}

\title{
LAYER FORMATION BY INTERDIFFUSION BETWEEN SOME REACTOR CONSTRUCTION METALS
}

J. Howard Kittel

METALLURGY DIVISION

June 17,1949

\footnotetext{
Operated by The University of Chicago under

Contract W-31-109-eng-38
}

1 


\title{
LAYER FORMATION BY INTERDIFFUSION BET WEEN SOME REACTOR CONSTRUCTION METALS
}

\author{
J. Howard Kittel
}

\section{INTRODUCTION}

The present design of the Experimental Breeder Reactor calls for numerous metal-to-metal contacts. Additional contacts may result because of dimensional changes or warping of the fuel elements after the pile has been operated for a length of time. The metal-to-metal contacts will generally occur under reducing conditions so that the contacting surfaces will be quite clean and usually free of oxide films. The presence of such conditions, along with the elevated temperatures associated with normal operation of the reactor, makes it likely that many of the metal-to-metal contacts will in effect act as diffusion couples, i.e., continuous interpenetration of two adjoining metals may occur.

The possible existence of diffusion couples in the reactor is a matter of some importance for two reasons: (a) the possibility of radioactive or other undesirable elements reaching the coolant stream with attendant contamination of pumps, heat exchangers, etc.; and (b) the formation of solid bonds or welds which might make difficult the removal of fuel rods and other metal parts.

The reactor components which normally will be in contact in the hottest part of the pile are the following:

1. Fuel rods and fuel rod spacers.

2. Fuel rod jackets and fuel rod spacers.

In addition, the following components may be in contact, should warping of dimensional changes occur in the assembled fuel elements:

1. Fuel rods and fuel rod jackets.

2. Fuel rod jackets (one with another).

3. Fuel rod jackets and separating plates.

4. Fuel rod jackets and plate into which the lower end of the assembled fuel rod is inserted.

The tendency towards dimensional instability which uranium exhibits when subjected to repeated heating cycles presents the possibility that the assembled fuel rods will deform to some extent during the anticipated normal use of the reactor. 
In order to study the diffusion reaction characteristics of the metals which have been proposed for use in the pile, a number of experiments have been completed in which many combinations of the proposed metals have been given diffusion treatments at various elevated temperatures for extended lengths of time. The metals being studied are beryllium, columbium, iron, molybdenum, nickel, tantalum, titenium, uranium, tungsten, zircionium, and 347 stainless steel. The above metals have all been used in a commercially pure state.

The experimental temperatures ranged from $400^{\circ}$ to $800^{\circ} \mathrm{C}$., and the durations of the diffusion treatments ranged from 6 to 48 days. With the exception of titanium, over 400 diffusion couples representing all possible combinations of the above eleven metals have been made and examined after diffusion anneals. Titanium was not on hand during most of the investigation, and at the time of writing it has been tested only against uranium and 347 stainless steel at $500^{\circ} \mathrm{C}$.

A series of tests was also made to evaluate the strengths of the bonds formed when interdiffusion of the metals occurred.

\section{APPARATUS AND PROCEDURE}

Rates of Layer Formation

The initial requirement for specimens which are required to provide reliable data on the interdiffusion of metals is that flawless contact be es tablished between uncontaminated surfaces of the metals to be studied. With this requirement in mind, as well as the consideration that a large number of diffusion couples would be needed for the investigation, diffusion specimens in a holder shown assembled in Figure 1 were used in the experiments.

Essentially, the specimens were small sheets of material compressed together in a plastically deformed container. The specimens themselves measured 3/8"x 3/4" and varied in thickness from $0.055^{\prime \prime}$ to $1 / 8$ ". Each sur face of each specimen which was to contact another specimen was metallographically polished through 3/0 emery paper, with the final polish always being in the direction of the longer dimension of the specimen. In order to prevent oxide contamination of the surfaces of the uranium specimens, which occurred within a few minutes after emery polishing, they were electropolished after the final polish on emery paper. A series of tests made with freshly emery-polished uranium specimens and electro-polished specimens showed no differences in diffusion reaction rates.

The specimen holders were $3 / 4$ " long and were cut from $7 / 8$ " square cold-rolled 1020 steel bar stock. A $3 / 8$ " square hole was drilled through each specimen in the $3 / 4$ " direction. In this square hole from 4 to 8 specimens were placed, after which the as sembled specimens and holder were 
compressed under 70,000 pounds in a direction normal to the polished surfaces of the specimens. The compression load was sufficient to plastically deform the holder and, to some extent, the specimens themselves, depending upon their hardness. This procedure was found to be not only simple and rapid, but yielded the required perfect contact between the ciiffusion metals in all but about $1 \%$ of the tests. A further advantage was that each as sembled holder contained up to 7 diffusion interfaces, a factor which greatly shortened the metallographic work involved in the microexaminations after the tests.

For diffusion treatments, groups of the assembled specimens were annealed in evacuated stainless steel containers in which was placed sufficient NaK alloy to completely cover the specimens. The NaK served as an efficient heat transfer medium and also minimized oxidation of the specimens. Each container, in which was constructed a well for a thermocouple, was heated in a vertical tube furnace. In most of the tests the variation from the desired temperature was less than \pm 5 degrees. Occasionally fluctuations somewhat larger than this were encountered.

The only uncertainty as to the annealing time is that introduced by the period of heating and cooling, and errors from this source are believed to be less than two hours in ail tests. "This is about $1.5 \%$ error in the sixday tests and correspondingly less in the longer tests.

After a diffusion-anneal the assembled specimens were cut as shown in Figure 1 and metallographically polished for photomicrography of the diffusion interfaces. In many cases the balance of an assembled specimen, after removal of a section for metallography, was returned to the diffusion treatment and after further annealing again sectioned for metallographic examination. One assembled specimen, therefore, could provide three metallographic sections, each of which would have been annealed at the same temperature but for different lengths of time:

Most of the photomicrographs were made at magnification of 250. If reaction layers were observed, their maximum total thickness was measured on the photomicrograph with a scale reading to $1 / 64$ ". This procedure provided a layer thickness, measurement accuracy of $\pm 3 \times 10^{-5}$ inch. In uncertain cases photomicrographs at a higher magnification were: made, with a correspondingly greater precision of layer thickness determination. Photomicrographs were made in areas believed to be representative of the entire specimen. In those cases where irregular layers were formed, the thickest. portion of the layer observed in a visual microscopic examination was measured. Occasionally, therefore, thickness measurements appear in the data which are larger than indicated by the corresponding photomicrograph:

For each diffusion couple, many trials were made to find the etchant which would most clearly delineate the reaction layers. In some cases an unetched specimen was found to show the layers more clearly. Uranium 
specimens were generally heated in air to oxidize reaction layers formed with the other metals.

Strengths of Diffusion Bonds

The first attempts to evaluate the strengths of the bonds were made with apparatus designed to force together, while submerged in NaK at the test temperature, the ends of cylinders made of the various metals. It was hoped that should bonding or welding occur, tensile specimens might be machined from the bonded metal. Difficulties were experienced in obtaining the contact required, so that specimens of the type shown in Figure 2 were used. The latter type of specimen provided shear stress data and was much simpler to use, for it was compressed and diffusion-annealed in the same specimen holder shown in Figure 1. The specimen shown in Figure 2 was tested in shear by imposing a tensile loading. A number of similar specimens were also used with short extended ends and were sheared by compression.

\section{RESULTS AND DISCUSSION}

\section{Rates of Layer Formation}

In many of the diffusion couples which were tested no reaction layers were noted. These combinations are listed in Table I. It will be noted that practically all of the couples which showed no evidence of reaction cortain at least one of the high-melting metals columbium, molybdenum, tantalum, or tungsten. The association of high-melting metals with the specimens showing an absence of diffusion layers is not unexpected, for it is known that rates of diffusion at a given temperature are lower the higher the melting points of the metals involved. ${ }^{1}$

It should be remembered that in the case of Mo-W and other alloy sys tems which contain no intermediate phases one would ordinarily not expect to observe reaction layers or any change in the microstructure at the interface. Terminal solid solutions formed by interdiffusion of two metals are continuous with the pure metals and thus cannot ordinarily be visibly defined by metallographic techniques. A change in microstructure might appear, however, if microconstituents resulting from impurities showed differing solubilities in the solid solutions compared to the originally pure metal. In some specimens there were indications that such a process had taken place.

Table II lists those diffusion couples which gave uncertain results. Most of the combinations listed are those which appeared to have reacted, but either the reaction layers were so thin that accurate measurement was not: possible or a zone with poorly defined limits was observed. The remainder of the combinations are those which yielded non-reprodicible data, probably owing to separation of the interface during the diffusion anneals. 
Table I

DIFFUSION COUPLES IN WHICH NO REACTION LAYERS WERE NOTED AFTER 6 DAYS OR MORE

\begin{tabular}{|c|c|c|c|c|}
\hline $500^{\circ}$ & $600^{\circ}$ & $650^{\circ}$ & $700^{\circ}$ & $800^{\circ}$ \\
\hline $\mathrm{Cb}-\mathrm{Fe}$ & $\mathrm{Cb}-\mathrm{U}$ & $\mathrm{Fe}-\mathrm{Zr}$ & $\mathrm{Be}-\mathrm{W}$ & Mo-W \\
\hline $\mathrm{Cb}-\mathrm{Mo}$ & Fe-Mo & Mo-Ta & $\mathrm{Cb}-\mathrm{Ta}$ & \\
\hline $\mathrm{Cb}-\mathrm{Ni}$ & $\mathrm{Fe}-\mathrm{Ta}$ & & $\mathrm{Cb}-\mathrm{W}$ & \\
\hline $\mathrm{Cb}-\mathrm{Ta}$ & $\mathbf{F e}-\mathrm{W}$ & & $\mathrm{Fe}-\mathrm{W}$ & \\
\hline $\mathrm{Cb}-\mathrm{W}$ & $\mathrm{Mo}-\mathrm{Ni}$ & & $\mathrm{Fe}-\mathrm{Zr}$ & \\
\hline $\mathrm{Cb}-\mathrm{U}$ & Mo-Ta & & Mo-Ta & \\
\hline $\mathrm{Cb}-\mathrm{Zr}$ & Mo-W & & Mo-W & \\
\hline $\mathrm{Fe}-\mathrm{Mo}$ & $\mathrm{Ni}-\mathrm{Ta}$ & & Ta-347 S.S. & \\
\hline $\mathbf{F e}-\mathrm{Ta}$ & $\mathrm{Ni}-\mathrm{W}$ & & $\mathrm{W}-\mathrm{Zr}$ & \\
\hline $\mathrm{Fe}-\mathrm{W}$ & Ta-347 S.S. & & W-347 S.S. & \\
\hline Mo-Ta & W-347 S.S. & & & \\
\hline Mo-W & & & ? & \\
\hline Mo-347 S.S. & & & & \\
\hline $\mathrm{Ni}-\mathrm{W}$ & & & & \\
\hline Ta-347 S.S. & & & & \\
\hline
\end{tabular}

Table II

DIFFUSION COUPLES IN WHICH UNCERTAIN RESULTS WERE NOTED AFTER 6 DAYS OR MORE

\begin{tabular}{|c|c|c|c|c|}
\hline $500^{\circ}$ & $600^{\circ}$ & $650^{\circ}$ & $700^{\circ}$ & $750^{\circ}$ \\
\hline $\mathrm{Fe}-\mathrm{U}$ & $\mathrm{Ta}-\mathrm{U}$ & Fe-Mo & $\mathrm{Cb}-\mathrm{U}$ & $\mathrm{Cb}-\mathrm{U}$ \\
\hline $\mathrm{Fe}-347 \mathrm{~S}: \mathrm{S}$ & $W-U$ & Ta-347 S.S. & $\mathrm{Cb}-\mathrm{Mo}$ & $\mathrm{Fe}-\mathrm{Ta}$ \\
\hline Mo-U & & & $\mathrm{Cb}-\mathrm{Fe}$ & $\mathrm{Fe}-\mathrm{W}$ \\
\hline $\mathrm{Ni}-347$ S.S. & & & $\mathrm{Cb}-347$ S.S. & $\mathrm{Mo}-\mathrm{Ta}$ \\
\hline $\mathrm{T} a-\mathrm{U}$ & & & Fe-Ta & $\mathrm{Ni}-\mathrm{W}$ \\
\hline $\mathrm{Ta}-\mathrm{Zr}$ & & & Mo-347 S.S. & $\mathrm{Ta}-\mathrm{U}$ \\
\hline $\mathrm{W},-\mathrm{U}$ & & & $\mathbf{N i}-\mathbf{W}$ & Ta-347 S.S. \\
\hline$U-Z r$ & & & $\mathrm{Ta}-\mathrm{U}$ & $W-U$ \\
\hline$\therefore$ & 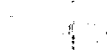 & & $W-U$ & W-347 S.S. \\
\hline
\end{tabular}


Figures 3, 4, 5, and 6(a) and (b) show log time vs. log thickness curves for reaction layers formed respectively at $500,600,650$, and $700^{\circ} \mathrm{C}$. The log-log plot of the data was chosen on the basis of results obtained in similar tests by Lustman and Mehl. ${ }^{2}$ They found that the growth of diffusion reaction layers as a function of time may be represented by the general parabolic equation

$$
\mathbf{x}^{\mathrm{n}}=\mathbf{K t}
$$

where

$$
\begin{aligned}
\mathbf{x} & =\text { thickness } \\
\mathbf{n} & =\text { reaction index } \\
\mathbf{K} & =\mathbf{r} \in \Delta c \text { ction-rate constant } \\
\mathbf{t} & =\text { time }
\end{aligned}
$$

For a given temperature, a particular value of $\mathrm{n}$ is found by taking the reciprocal of the slope of the straight line obtained when the logarithm of thickness is plotted against the logarithm of time.

The above equation provides a useful relation for extrapolation to times or layer thicknesses other than those plotted in Figures 3 and 6 . To facilitate this, Table III was prepared, which lists values of $n$ and $K$ for the time-thickness curves presented. It is emphasized that those values of $n$ and $\mathrm{K}$ which are based on only two data points should be considered as only tentative. In any case it should be remembered that use of metals which analyse appreciably different than the commercially pure materials used in this investigation may lead to different results because of the effect of differing amounts of additional elements on diffusion rates.

Data on the effect of temperature on the growth of reaction layers, though largely incomplete, are shown in Figure $7(\mathrm{a}),(\mathrm{b})$, and (c) where the total layer thickness, $T$, formed in six days is plotted against the reciprocal of the absolute temperature of diffusion. In accordance with the findings of Lustman and $\mathrm{Mehl}^{2}$ the data points, when more than two are available, appear to lie near straight lines. Exceptions are $\mathrm{Be}-\mathrm{Ni}$ between $650^{\circ}$ and $700^{\circ} \mathrm{C}$. and $\mathrm{Ni}-347$ stainless steel between $600^{\circ}$ and $700^{\circ} \mathrm{C}$.

By determining the slopes of the curves shown in Figure $7(a),(b)$, and (c) and using the Arrhenius equation $T=A e \exp -Q / R T$, it is possible to obtain values of the activation energy for diffusion layer formation. Values of the activation energy $Q$, with the temperature ranges in which they were determined, are summarized in Table IV. The values of $Q$ obtained from only two points are to be regarded as only tentative. 
VALUES OF REACTION RATE CONSTANTS

\begin{tabular}{|c|c|c|c|c|c|}
\hline Di ffusion Couple & " & Temp., ${ }^{\circ} \mathrm{C}$ & & $\mathrm{n}$ & $\mathrm{K}$, in. /day \\
\hline $\mathrm{Be}-\mathrm{Ni}$ & & 500 & & 7.6 & $4.6 \times 10^{-23}$ \\
\hline $\mathrm{Be}-\mathrm{Zr}$ & & 500 & & 1.7 & $1.7 \times 10^{-6}$ \\
\hline $\mathrm{Ni}-\mathrm{U}$ & & 500 & & 3.0 & $7.4 \times 10^{-12}$ \\
\hline $\mathrm{U}-347$ S.S. & & 500 & & 2.9 & $1.1 \times 10^{-11}$ \\
\hline $\mathrm{Be}-\mathrm{Ni}$ & & 600 & & 1.6 & $5.3 \times 10^{-6}$ \\
\hline $\mathrm{Be}-\mathrm{U}$ & & 600 & & 2.0 & $1.9 \times 10^{-8}$ \\
\hline $\mathrm{Fe}-\mathrm{U}$ & & 600 & & 2.6 & $7.9 \times 10^{-13}$ \\
\hline Mo-U & & 600 & & 2.7 & $1.3 \times 10^{-11}$ \\
\hline $\mathrm{Ni}-\mathrm{U}$ & & 600 & & 3.0 & $3.9 \times 10^{-11}$ \\
\hline $\mathrm{Ni}-347$ S.S. & & 600 & & 1.3 & $2.1 \times 10^{-6}$ \\
\hline U-347 S.S. & & 600 & & 2.5 & $1.4 \times 10^{-8}$ \\
\hline $\mathrm{Be}-\mathrm{Fe}$ & & 650 & & 1.2 & $6.0 \times 10^{-5}$ \\
\hline $\mathrm{Be}-\mathrm{Ni}$ & & 650 & & 1.2 & $7.3 \times 10^{-5}$ \\
\hline $\mathrm{Be}-\mathrm{Ta}$ & & 650 & & 2.2 & $7.6 \times 10^{-9}$ \\
\hline $\mathrm{Be}-\mathrm{Zr}_{\mathbf{r}}$ & & 650 & & 1.5 & $2.6 \times 10^{-5}$ \\
\hline Be-347 S.S. & & 650 & & 2.5 & $4.8 \times 10^{-8}$ \\
\hline $\mathrm{Cb}-\mathrm{Ni}$ & & 650 & & 0.7 & $2.4 \times 10^{-4}$ \\
\hline $\mathrm{Cb}-\mathrm{Zr}$ & & 650 & & 1.4 & $1.5 \times 10^{-6}$ \\
\hline $\mathrm{Fe}-\mathrm{Ni}$ & & 650 & & 2.3 & $2.9 \times 10^{-8}$ \\
\hline Mo-Zr & & 650 & & 1.5 & $2.3 \times 10^{-7}$ \\
\hline $\mathrm{Ni}-\mathrm{Zr}$ & & 650 & & 1.9 & $2 . .2 \times 10^{-9}$ \\
\hline Ni-347 S.S. & & 650 & & 1.6 & $7.0 \times 10^{-7}$ \\
\hline$T a-Z r$ & . & 650 & & 2.1 & $1.7 \times 10^{-9}$ \\
\hline $\mathrm{Zr}-347$ S.S. & & 650 & & 1.1 & $3.0 \times 10^{-6}$ \\
\hline $\mathrm{Be}-\mathrm{Cb}$ & & 700 & & 1.7 & $3.3 \times 10^{-7}$ \\
\hline $\mathrm{Be}-\mathrm{Fe}$ & & 700 & & 1.5 & $1.3 \times 10^{-5}$ \\
\hline $\mathrm{Be}-\mathrm{Mo}$ & & 700 & & 0.6 & $1.8 \times 10^{-4}$ \\
\hline $\mathrm{Be}-\mathrm{Ni}$ & & 700 & & 1.2 & $4.3 \times 10^{-4}$ \\
\hline $\mathrm{Be}-\mathrm{Zr}$ & & 700 & & 1.2 & $2.2 \times 10^{-4}$ \\
\hline $\mathrm{Be}-347 \mathrm{~s} . \mathrm{S}$ & & 700 & & 2.3 & $1.6 \times 10^{-7}$ \\
\hline $\mathrm{Cb}-\mathrm{Ni}$ & & 700 & $!$ & $1: 0$ & $8.4 \times 10^{-5}$ \\
\hline $\mathrm{Cb}-\mathrm{Zr}$ & & 700 & $!$ & 2.3 & $2.6 \times 10^{-8}$ \\
\hline Fe-Mo & & 700 & 1 & 2.0 & $3.6 \times 10^{-9}$ \\
\hline $\mathrm{Fe}-\mathrm{Ni}$ & $:$ & 700 & 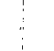 & 2.2 & $5.5 \times 10^{-8}$ \\
\hline $\mathrm{Mo}-\mathrm{Ni}$ & & 700 & $i$ & 1.4 & $3.6 \times 10^{-7}$ \\
\hline Mo-U & & 700 & 1 & 1.3 & $4.1 \times 10^{-5}$ \\
\hline $\mathrm{Mo}-\mathrm{Zr}$ & & 700 & 4 & 1.0 & $1.3 \times 10^{-4}$ \\
\hline $\mathrm{Ni}-\mathrm{Ta}$ & & 700 & 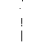 & 0.6 & $1.1 \times 10^{-3}$ \\
\hline $\mathrm{Ni}-\mathrm{U}$ & : & 700 & 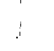 & 3.0 & $1.0 \times 10^{-8}$ \\
\hline $\mathrm{Ni}-\mathrm{Zr}$ & & 700 & & 0.7 & $9.6 \times 10^{-4}$ \\
\hline $\mathrm{Ni}-347$ S.S. & & 700 & & 1.5 & $1.1 \times 10^{-6}$ \\
\hline $\mathrm{Ta}-\mathrm{W}$ & & 700 & & 1.4 & $3.6 \times 10^{-7}$ \\
\hline $\mathrm{Ta}-\mathrm{Zr}$ & & 700 & & 2.0 & $6.0 \times 10^{-9}$ \\
\hline $\mathrm{U}-\mathrm{Zr}$ & & 700 & & 3.0 & $2.4 \times 10^{-13}$ \\
\hline $\mathrm{Zr}-347$ s.S. & & 700 & & 1.7 & $1.8 \times 10^{-7}$ \\
\hline
\end{tabular}


Table IV

ACTIVATION ENERGIES FOR REACTION-LAYER FORMATION

\begin{tabular}{lrr} 
Diffusion Couple & $Q$, cal, per mole & Temp. Range, ${ }^{\circ} \mathrm{C}$. \\
\cline { 1 - 2 } $\mathrm{Be}-\mathrm{Fe}$ & 12,100 & $650-700$ \\
$\mathrm{Be}-\mathrm{Ni}$ & 2,800 & $500-650$ \\
$\mathrm{Be}-\mathrm{U}$ & 22,800 & $600-650$ \\
$\mathrm{Be}-\mathrm{Zr}$ & 11,300 & $500-700$ \\
$\mathrm{Cb}-\mathrm{Ni}$ & 98,600 & $650-700$ \\
$\mathrm{Cb}-\mathrm{Zr}$ & 62,800 & $650-700$ \\
$\mathrm{Fe}-\mathrm{Mo}$ & 20,800 & $650-800$ \\
$\mathrm{Fe}-\mathrm{Ni}$ & 3,300 & $650-700$ \\
$\mathrm{Fe}-\mathrm{U}$ & 20,400 & $600-700$ \\
$\mathrm{Mo}-\mathrm{Ni}$ & 29,400 & $700-800$ \\
$\mathrm{Mo}-\mathrm{U}$ & 41,200 & $600-800$ \\
$\mathrm{Mo}-\mathrm{Zr}$ & 59,500 & $650-700$ \\
$\mathrm{Ni}-\mathrm{Ta}$ & 35,700 & $700-800$ \\
$\mathrm{Ni}-\mathrm{U}$ & 16,800 & $500-700$ \\
$\mathrm{Ni}-\mathrm{Zr}$ & 93,000 & $650-700$ \\
$\mathrm{Ta}-\mathrm{Zr}$ & 13,200 & $650-700$ \\
$\mathrm{U}-347$ S.S. & 17,700 & $500-700$ \\
$\mathrm{Zr}-347$ S.S. & 70,000 & $650-700$
\end{tabular}

Strength of Diffusion Bonds

Although all possible combinations of the metals (except titanium) were tested for strengths of bonds formed for six or more days at temperatures between 600 and $700^{\circ} \mathrm{C}$., only a few yielded bonds strong enough for $\because$ quantitative results. Most of the reaction layers were so weak that they 1 could be easily broken and separated with the fingers. In those cases where strong bonds or welds did result, the two metals forming the bond were usually metals known to form terminal solid solutions with one another. This was especially noticeable in the case of uranium, which consistently formed strong bonds with columbium, molybdenum, and zirconium - metals which are believed to be among those most soluble in solid uranium. No particular correlation between shear strength and time or temperature of bond formation was noted; although the Mo-U bonds formed at $600^{\circ}$ appeared to be somewhat stronger than those formed at $700^{\circ}$. The bond strength data are summarized in Table $\mathrm{V}$. Those combinations of metals which do not appear in the table showed negligible shear strengths. Difficulty was experienced in obtaining unoxidized specimens for this series of tests. Under ideal conditions, with no oxide penetration into the diffusion interface, it is likely that diffusion bonds would be obtained with shear strengths substantially higher than those reported in Table $\mathrm{V}$. 
$\underline{\text { Table V }}$

SHEAR STRENGTHS. OF BONDS FORMED BY DIFFUSION AFTER 6 OR MORE DAYS AT $600^{\circ}$ TO $700^{\circ} \mathrm{C}$.

\begin{tabular}{|c|c|c|c|}
\hline $\begin{array}{c}\text { Diffusion } \\
\text { Couple } \\
\end{array}$ & $\begin{array}{c}\text { No. of Specimens } \\
\text { Tested }\end{array}$ & $\begin{array}{l}\text { Avg. Shear Strength } \\
\text { of Bond, p.s.i. }\end{array}$ & Remarks \\
\hline $\mathrm{Cb}-\mathrm{U}$ & 6 & 4,000 & \\
\hline $\mathrm{Fe}-\mathrm{Ni}$ & 1 & 5,500 & \\
\hline $\mathrm{Fe}-\mathrm{U}$ & 2 & 5,500 & $\begin{array}{l}\text { Also two specimens } \\
\text { showed negligible } \\
\text { strength }\end{array}$ \\
\hline $\mathrm{Fe}-347$ S.S. & 1 & 15,500 & \\
\hline $\mathrm{Ni}-347$ S.S. & 1 & 16,500 & \\
\hline Mo-U & 10 & 10,000 & \\
\hline $\mathrm{Zr}-\mathrm{U}$ & 2 & 6,500 & \\
\hline $\mathrm{Zr}-\mathrm{U}$ & 1 & 5,500 & Diffused one day only \\
\hline $\mathrm{Zr}-347$ S.S. & 1 & 1,100 & \\
\hline
\end{tabular}

Microstructural Characteristics of Reaction Layers

Figures 8 through 36 show photomicrographs of the reaction interfaces of metal combinations which were observed to form layers. The photomicrographs were made from specimens diffused at $700^{\circ} \mathrm{C}$. , with the exception of $\mathrm{Be}-\mathrm{Ta}$, which was diffused at $650^{\circ}$, and $\mathrm{Ti}-\mathrm{U}$ and $\mathrm{Ti}-347$, which were diffused at $500^{\circ}$.

Be-Cb (Figure 8). Two layers of widely varying thickness are noted at $650^{\circ}$, while only one layer was observed to form at $700^{\circ}$. A peritectic may occur between $650^{\circ}$ and $700^{\circ}$. Layers appear to form mainly on columbium side of the interface.

Be-Fe (Figure 9). Two layers of wideiy varying thickness noted at $650^{\circ}$ and $700^{\circ}$. Layers form mostly on the beryllium side of the interface.

Be-Mo (Figure 10). One layer, extremely thin, noted at $700^{\circ}$.

Be-Ni (Figure 11). Two layers noted at $500^{\circ}, 600^{\circ}, 650^{\circ}$, and $700^{\circ}$. The layer nearer the beryllium is much thicker and at $600^{\circ}$ frequently showed a precipitated phase. In $700^{\circ}$ te sts the thick layer was observed to contain columnar grains, oriented perpendicularly to the interface.

Be-Ta (Figure 12). One layer observed at $650^{\circ}$. There are indications that the layer forms on the tantalum side of the interface. 
Be-U (Figure 13). One layer observed at $600^{\circ}, 650^{\circ}$, and $700^{\circ}$, which forms on the uranium side of the interface. The layer does not increase in thickness beyond about $0.0006 "$ ", probably because of severe cracking which is noted in the beryllium near the interface. The amount of cracking increases as the test time is increased.

Be-Zr (Figure 14). A layer forms on the zirconium side of the interface, with acicular grains projecting into the zirconium from the interface. There is some indication that the layer may be composed of two compounds, for under polarized light a light-colored constituent is consistently observed near the interface.

Be-347 Stainless Steel (Figure 15). At $500^{\circ}$ a very thin layer is noted. At $650^{\circ}$ and $700^{\circ}$ a thick layer is observed with an adjoining thinner layer containing a large proportion of precipitated particles. at $700^{\circ}$.

Cb-Mo (Figure 16). Very thin irregular layer observed after 24 days

$\mathrm{Cb}-\mathrm{Ni}$ (Figure 17). At $650^{\circ}$ two thin irregular layers appear on the columbium side of the interface. At $700^{\circ}$ much thicker layers are noted.

Cb-U (Figure 18). At $700^{\circ}$ a thin grey-colored irregular layer has been noted occasionally.

$\mathrm{Cb}-\mathrm{Zr}$ (Figure 19). Two layers observed at $650^{\circ}$ and $700^{\circ}$. The layer formed nearer the zirconium at $700^{\circ}$ contains an acicular constituent with some tendency towards an orientation parallel to the interface.

Fe-Mo (Figure 20). A thin uniform layer forms at $650^{\circ}$ and $700^{\circ}$. Two layers are observed at $800^{\circ}$.

Fe-Ni (Figure 21). Two layers observed at $650^{\circ}$ and $700^{\circ}$. The layer nearer iron contains a fine-grained structure and may be partially transformed austenite.

Fe-U (Figure 22). An irregular grey-colored layer forms at $600^{\circ}$ and $700^{\circ}$, apparently on the uranium side of the interface.

Fe-347 Stainless Steel (Figure 23). At $650^{\circ}$ and $700^{\circ}$ an irregular outlining of the iron grains near the interface is observed. No layer formation is noted.

Mo-Ni (Figure 24). At $650^{\circ}$ one thin uniform layer is formed, while at $700^{\circ}$ two layers are observed. 
Mo-U (Figure 25). At $600^{\circ}$ two thin irregular layers are observed. At $700^{\circ}$ the layers are much thicker and are very uniform in thickness. The layer nearer the molybdenum frequently shows a gradation in response to etching, suggesting that it may cover a relatively large range of composition.

Mo-Zr (Figure 26). Two very thin layers observed at $650^{\circ}$. At $700^{\circ}$ the layer nearer the zirconium is much thicker.

Ni-Ta (Figure 27). Two irregular layers observed at $700^{\circ}$ and $800^{\circ}$.

Ni-U (Figures $28(\mathrm{a})$ and $28(\mathrm{~b}))$. Two layers observed at $500^{\circ}$, three layers at $600^{\circ}$, and five or more at $700^{\circ}$. The layers all appear to lie on the uranium side of the interface. The layer which adjoins the uranium shows a very irregular boundary which, when examined with polarized light (Figure 28(b)), does not appear to be related to the grain structure of the uranium. The nickel side of the interface frequently shows much cracking; and if the diffusion bond is broken, fracture occurs through this area, leaving the reaction layers attached to the uranium.

Ni-Zr (Figure 29). Two layers are noted at $650^{\circ}$, and three or more are observed at $700^{\circ}$. The layers appear to form on the zirconium side of the interface.

$\mathrm{Ni}-347$ Stainless Steel (Figure 30). One uniform layer forms at $600^{\circ}$, $650^{\circ}$, and $700^{\circ}$. The layer shows a fine-grained structure when heavily etched.

$\underline{\text { Ta-W }}$ (Figure 31). Two very irregular layers form at $700^{\circ}$.

Ta-Zr (Figure 32). One layer observed at $650^{\circ}$, and two noted at $700^{\circ}$. The layer adjoining the zirconium is similar in etching characteristics to a second phase originally present in the zirconium.

Ti-U (Figure 33). At least one irregular layer forms at $500^{\circ}$.

U-Zr (Figure 34). Thin layer noted, apparently formed on the uranium side of the interface.

U-347 Stainless Steel (Figure 35). One layer forms at $500^{\circ}$; three layers form at $600^{\circ}$ and $700^{\circ}$. The center layer is severely cracked, and fracture occurs through this zone when the interface is separated. At $700^{\circ}$, the cracking appears to prevent diffusion after about $0.004^{\prime \prime}$ of layers have been formed.

Zr-347 Stainless Steel (Figure 36). One layer observed at $650^{\circ}$ and $700^{\circ}$. The layer forms on the zirconium side of the interface. 


\section{Miscellaneous Tests}

Distortion due to cold work and recrystallization following cold work have been known in some cases to affect diffusion rates. 1 To determine possible effects of cold work on the rate at which reaction layers are formed between molybdenum and uranium, tests were made in which uranium was reacted with molybdenum which had been cold rolled to reductions of 0,10 , 20,40 , and 80 per cent. The test temperature, $700^{\circ} \mathrm{C}$., was about $200^{\circ}$ be low the recrystallization temperature of the molybdenum. Metallographic. examination showed no differences in the total thickness of the layers which formed.

To determine possible effects of recrystallization on the rate of formation of reaction layers between nickel and uranium, a similar series of tests was made in which the nickel was given cold reductions up to 80 per cent and diffused with uranium. In this case the test temperature, $700^{\circ} \mathrm{C}$, was about $100^{\circ}$ above the recrystallization temperature of the nickel. Again, no differences in reaction rate were found.

In conclusion, acknowledgment is made to Lowell $\mathrm{T}$. Lloyd, who performed the early tests, and to Maurice Odie, who did the metallography and photomicrography. 


\section{REFERENCES}

1. Mehl, Robert F.: Diffusion in Solid Metals. Trans. Am. Inst. Mining Met. Engrs., 122, $11-56$ (1936).

2. Lustman B. and Mehl, R. F.: Rate of Growth of Intermediate Alloy Layers in Structurally Analogous Systems. Trans. Am. Inst. Mining Met. Engrs., 147, 369-395 (1942). 
Figure I. Diffusion Specimens and Holder.

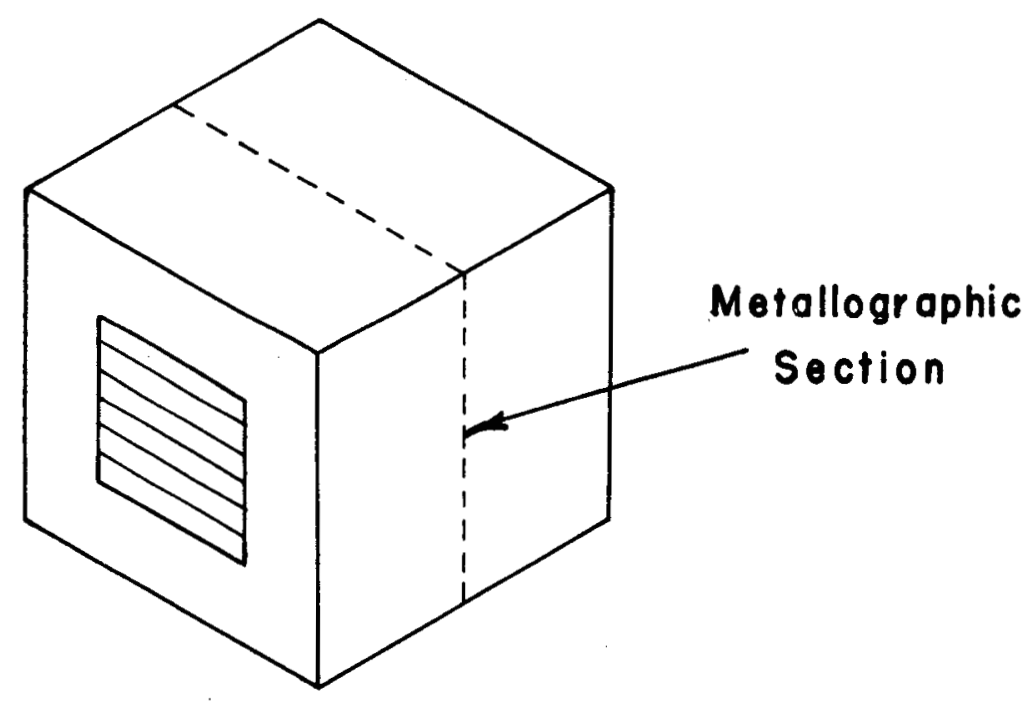

Figure 2. Specimen used for Testing Shear Strengths of Diffusion Bonds.

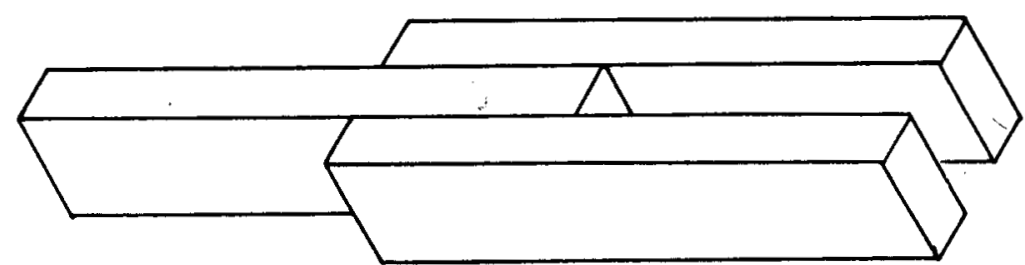


Figure 3. Thickness of Reoction Layers Formed at $500^{\circ} \mathrm{C}$.

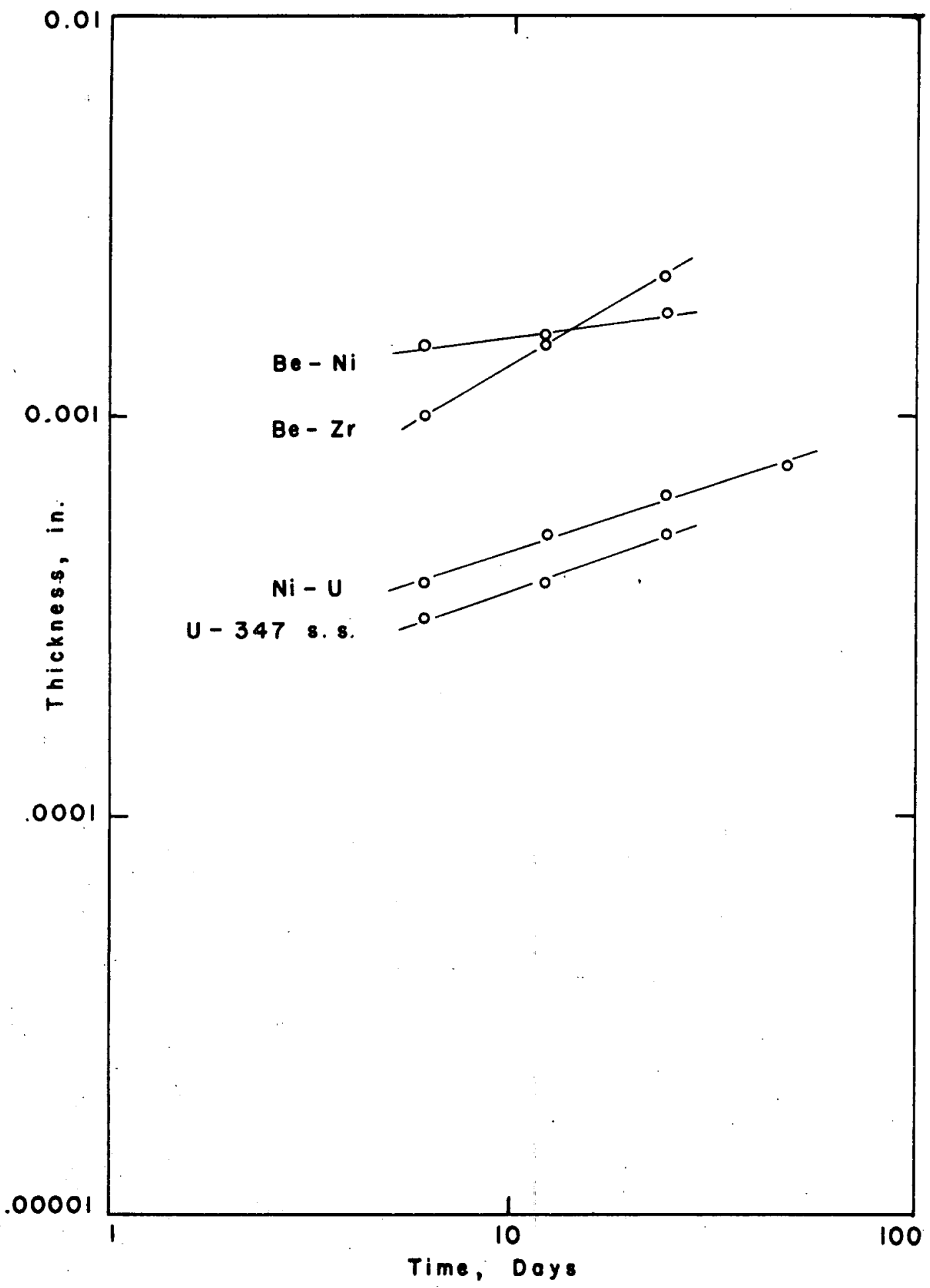


Figure 4. Thickness of Reoction Loyers Formed at $600^{\circ} \mathrm{C}$.

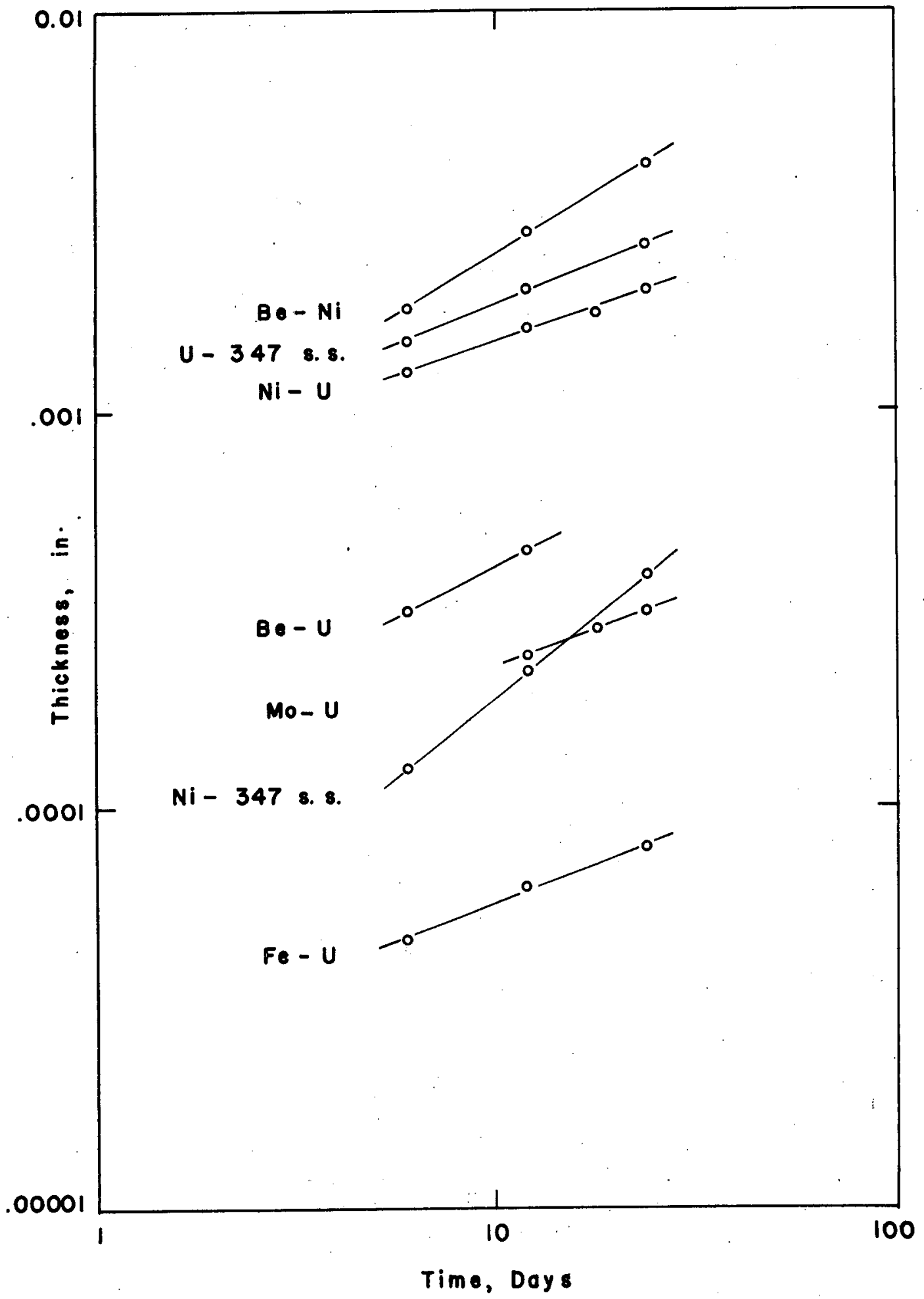


Figure 5. Thickness of Reaction Layers Formed of $650^{\circ} \mathrm{C}$.

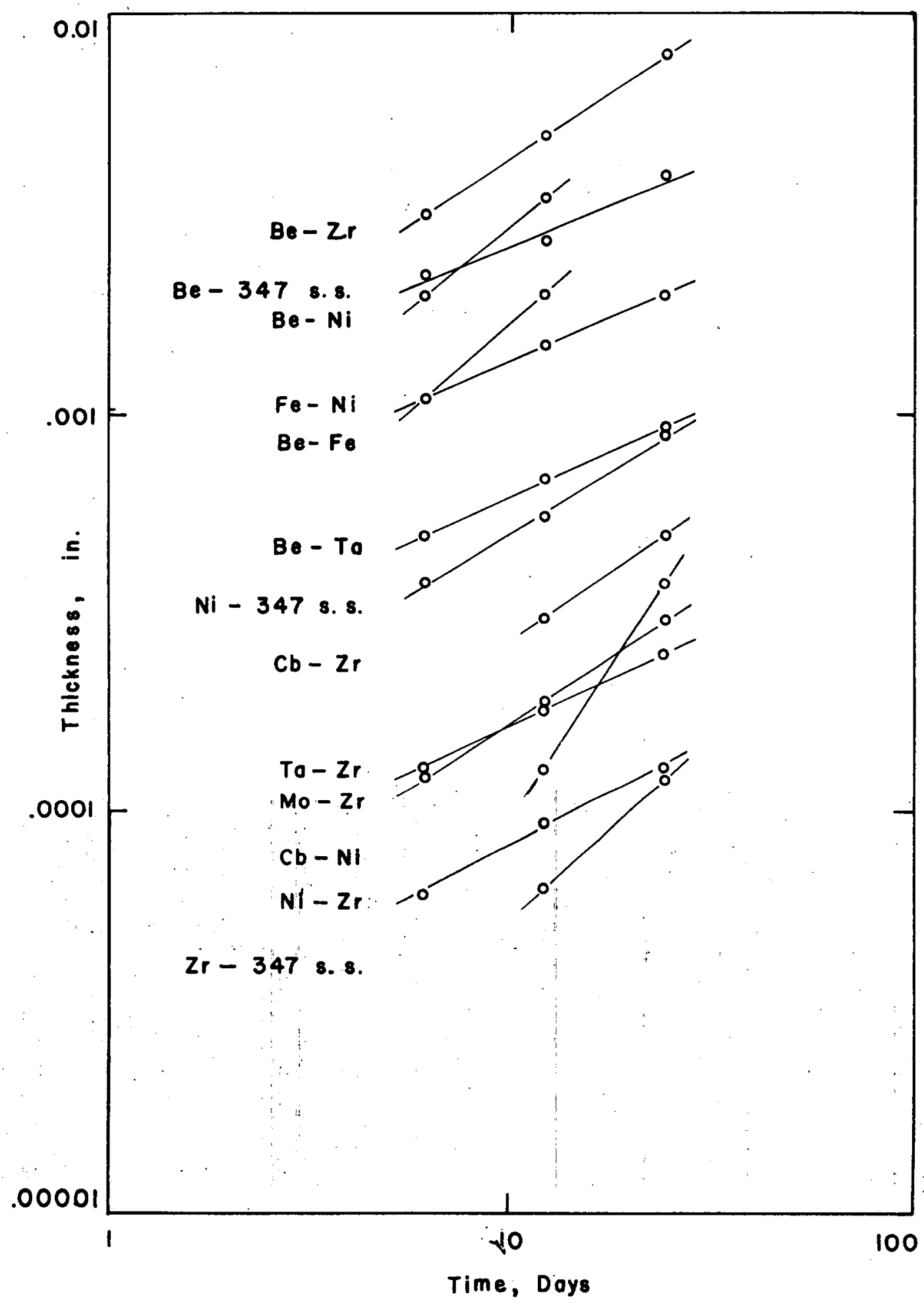


Figure $6(0)$. Thickness of Reaction Loyers Formed at $700^{\circ} \mathrm{C}$.

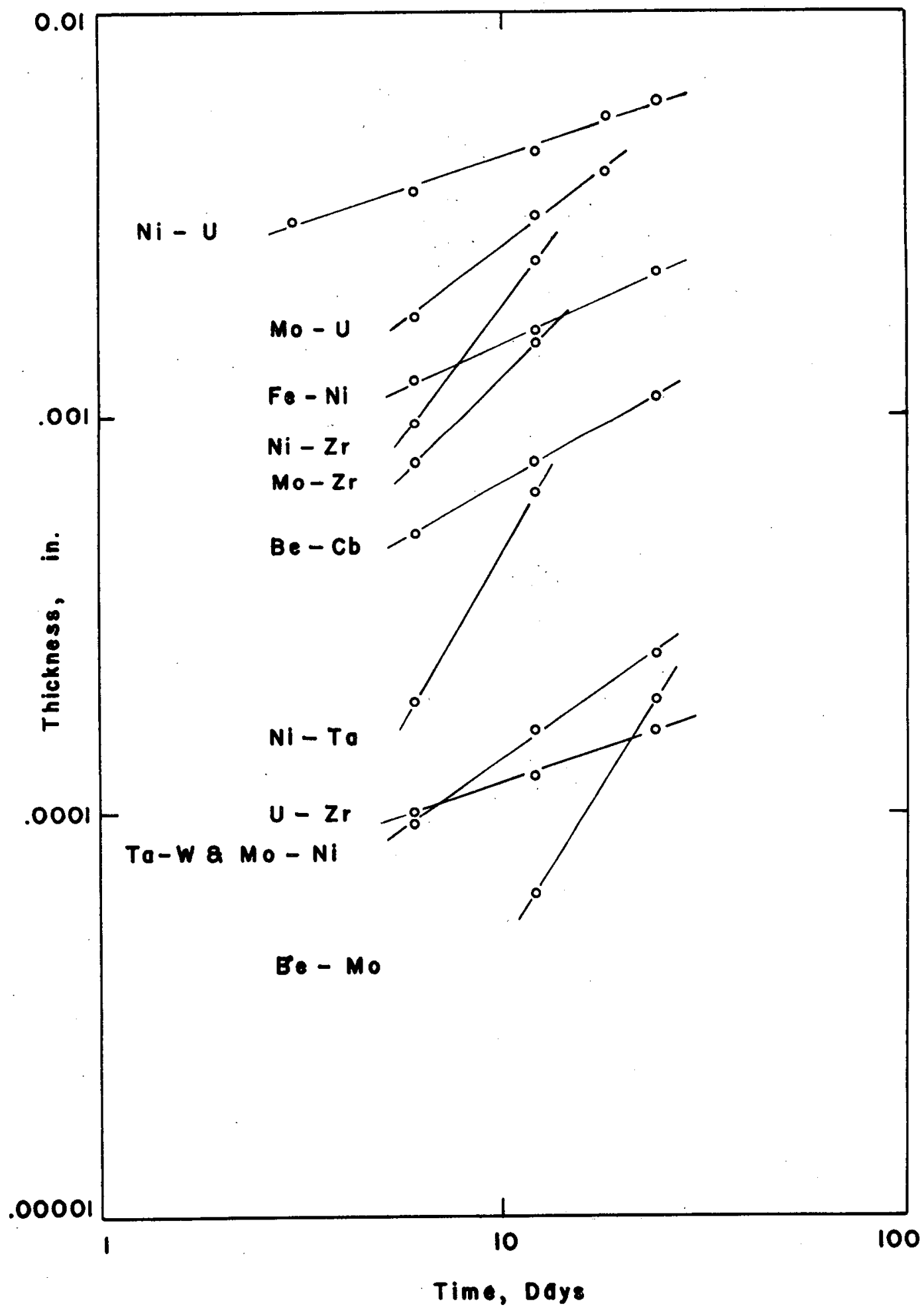


Figure 6 (b). Thickness of Reoction Layers Formed of $700^{\circ} \mathrm{C}$.

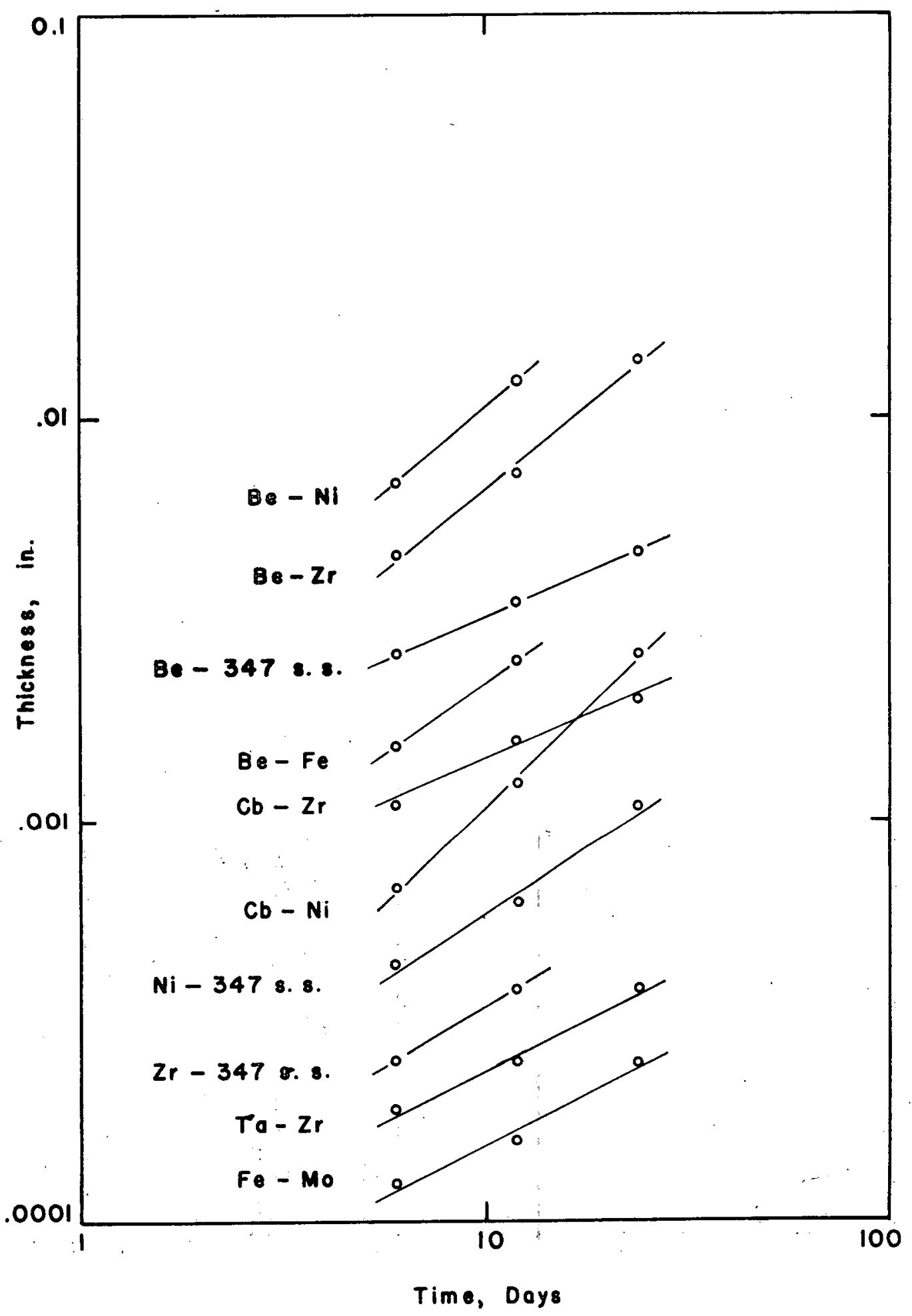


Figure $7(a)$. Thickness of Reaction Layers Formed in 6 Doys.

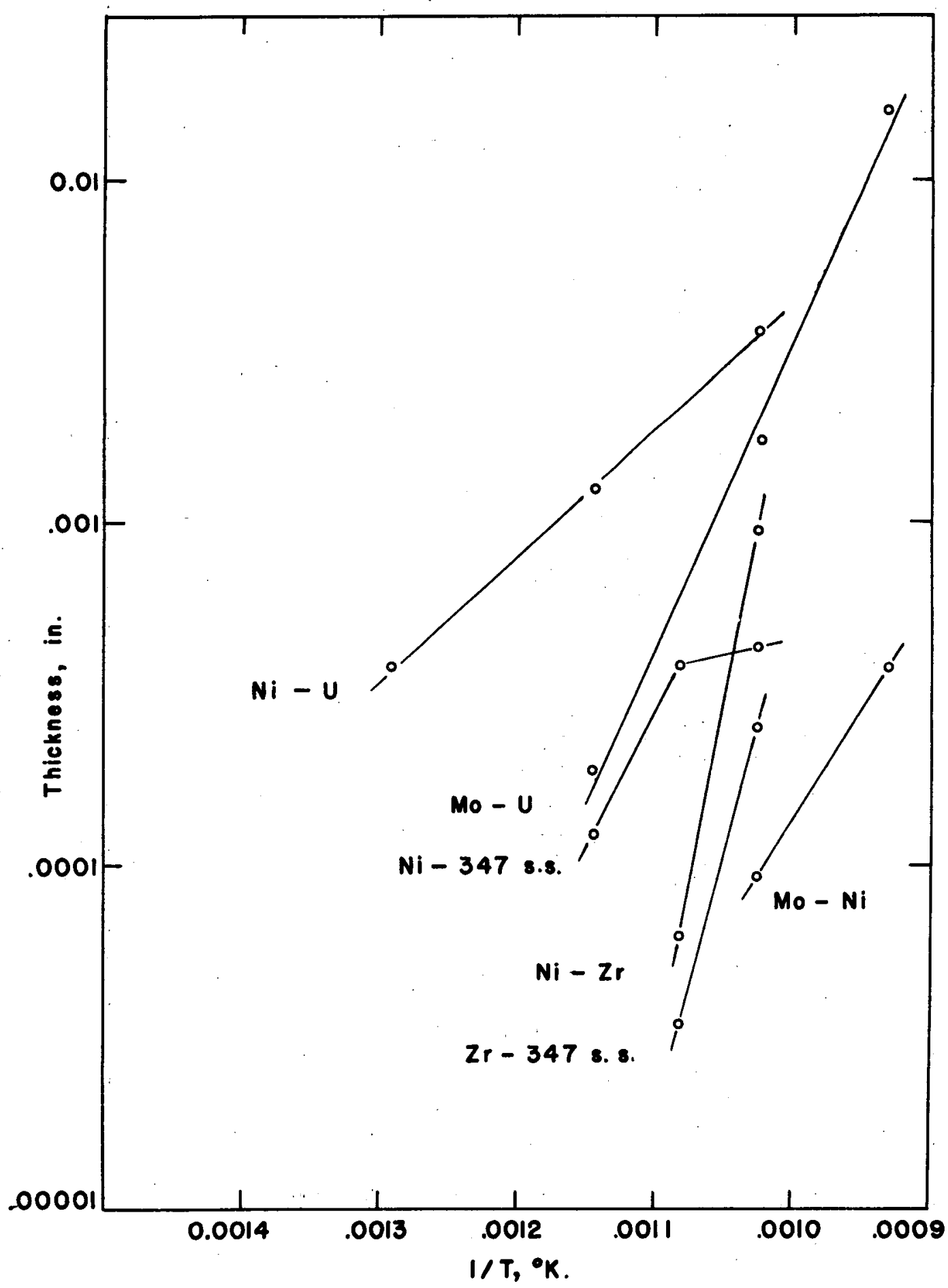


Figure 7 (b). Thickness of Reoction Layers Formed in 6 Days.

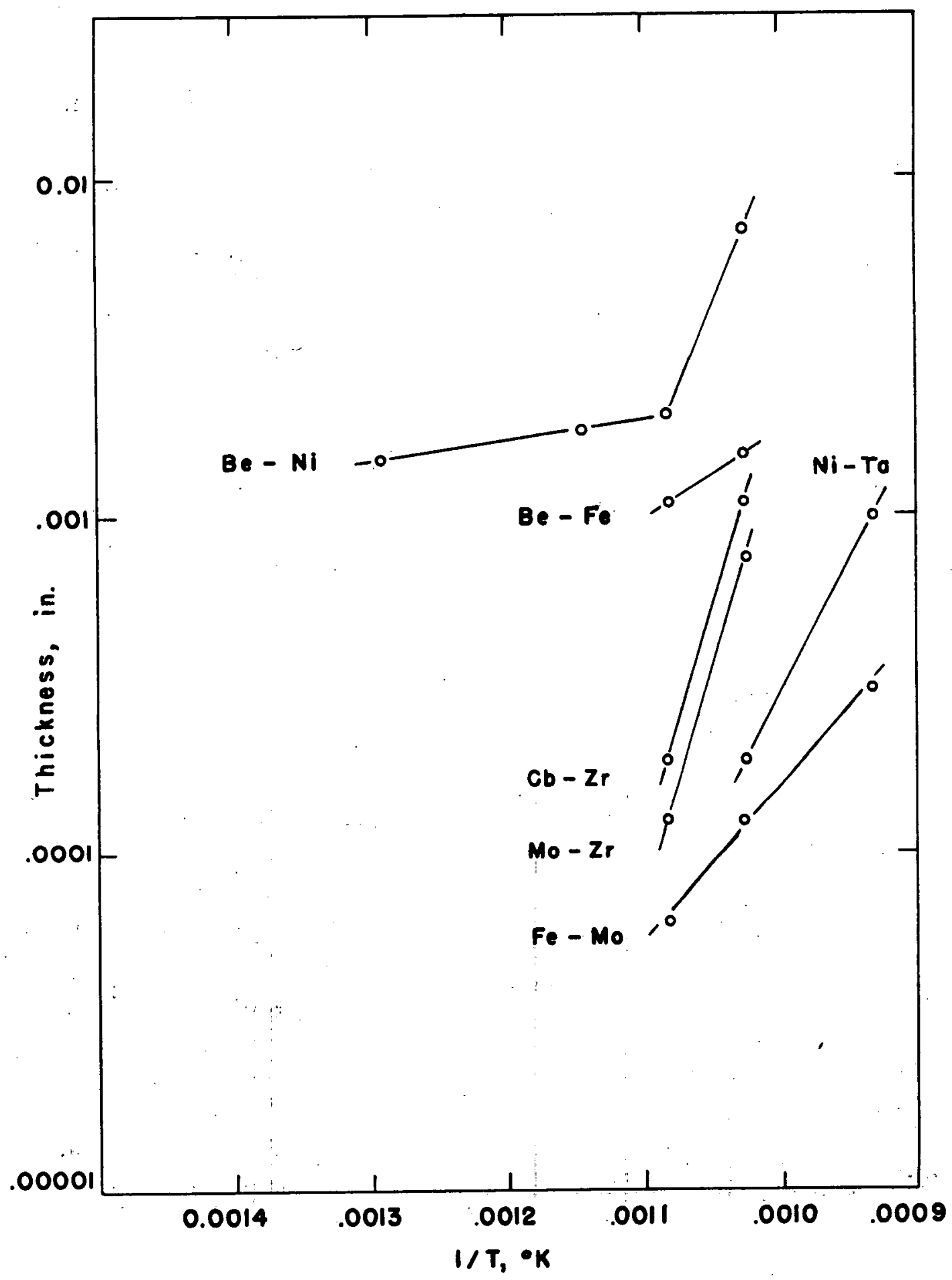


Flqure $7(\mathrm{c})$. Thickness of Reaction Layers Formed in 6 Days.

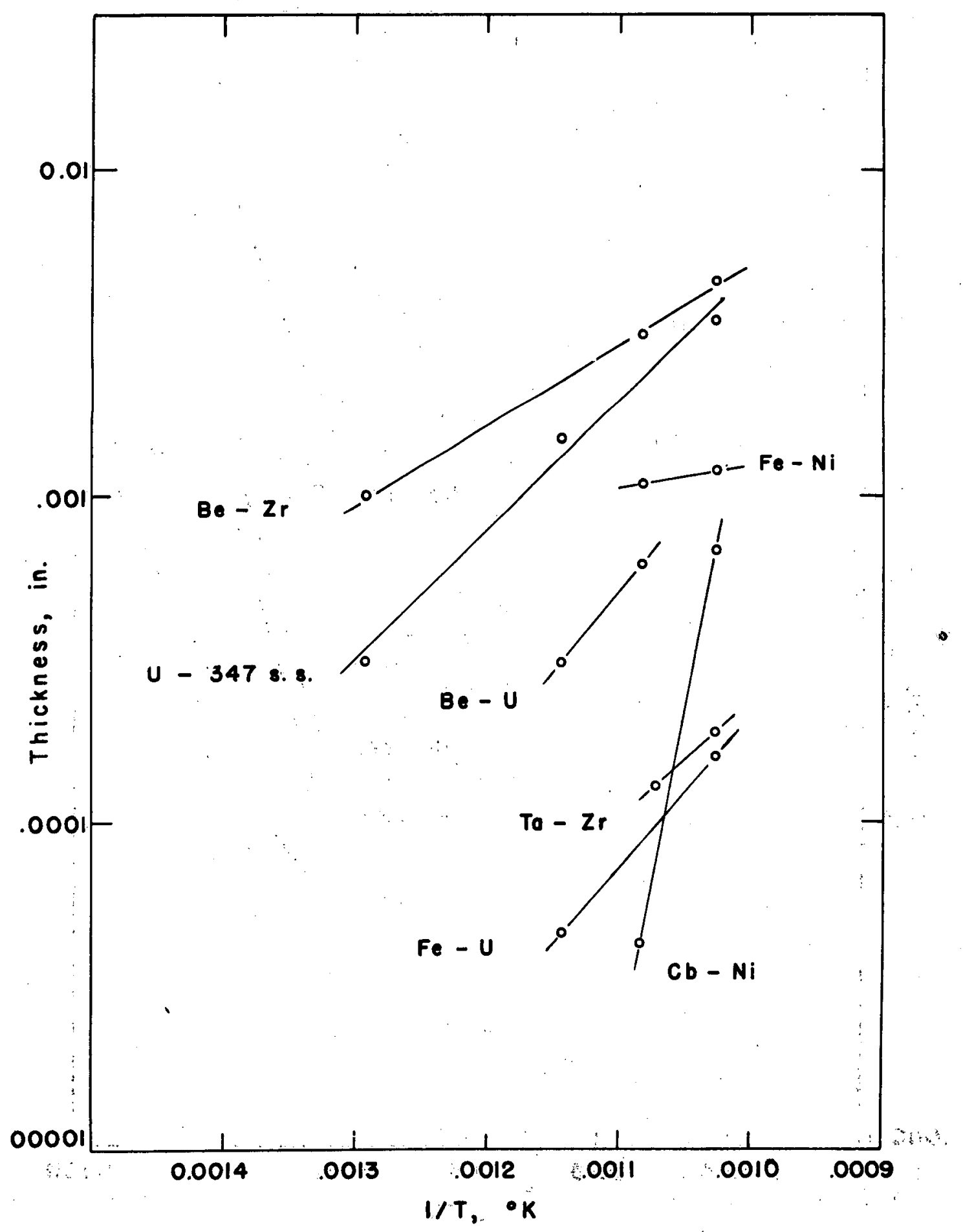




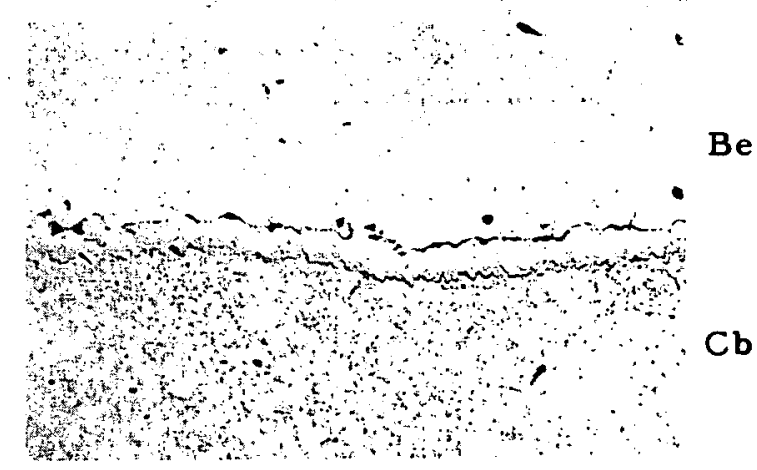

No. 5674

$250 x$

Figure 8

$\mathrm{Be}-\mathrm{Cb}$. Twelve days at $700^{\circ} \mathrm{C}$.

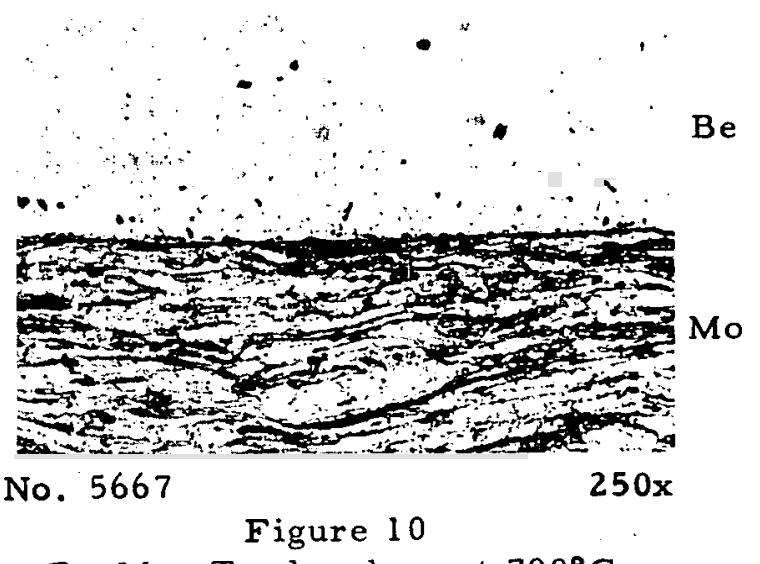

Be-Mo. Twelve days at $700^{\circ} \mathrm{C}$.

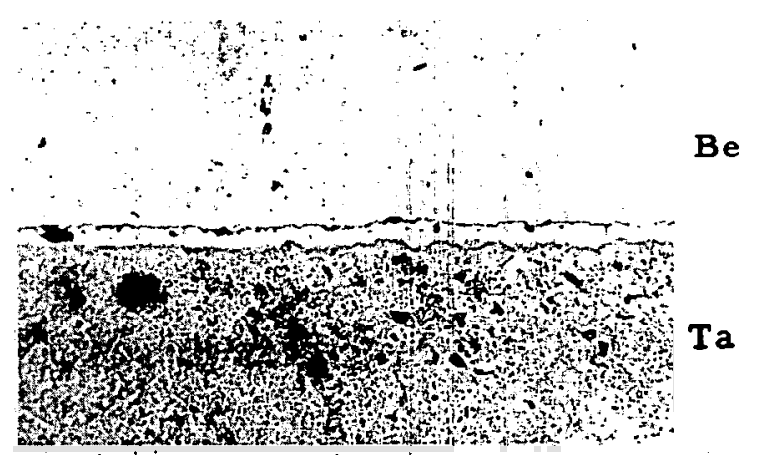

No. 5872 .

$\therefore 250 x$

Figure 12

$\mathrm{Be}-\mathrm{Ta}$ : Twelve days at $650^{\circ} \mathrm{C}$.

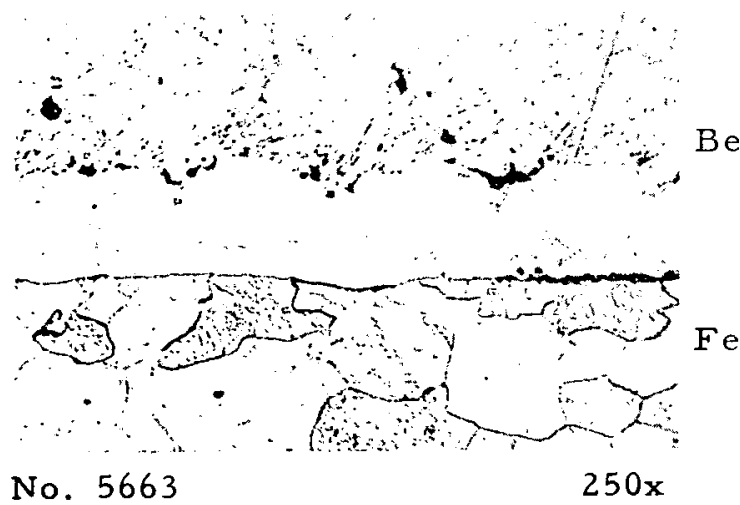

Figure 9

$\mathrm{Be}-\mathrm{Fe}$. Twelve days at $700^{\circ} \mathrm{C}$.
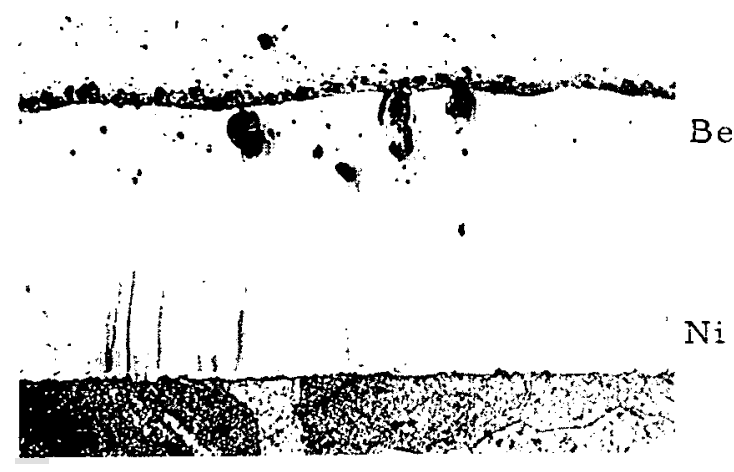

No. 5669

$100 x$

Figure 11

$\mathrm{Be}-\mathrm{Ni}$. Twelve days at $700^{\circ} \mathrm{C}$.
Be

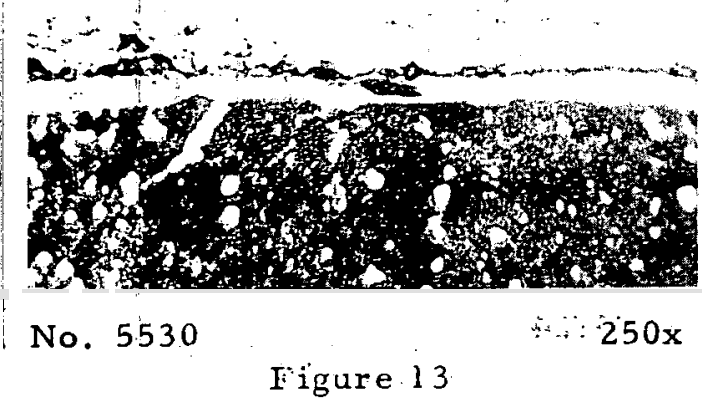

$\mathrm{Be}-\mathrm{U}$. Twelve days at $: 700^{\circ} \mathrm{C}$. 


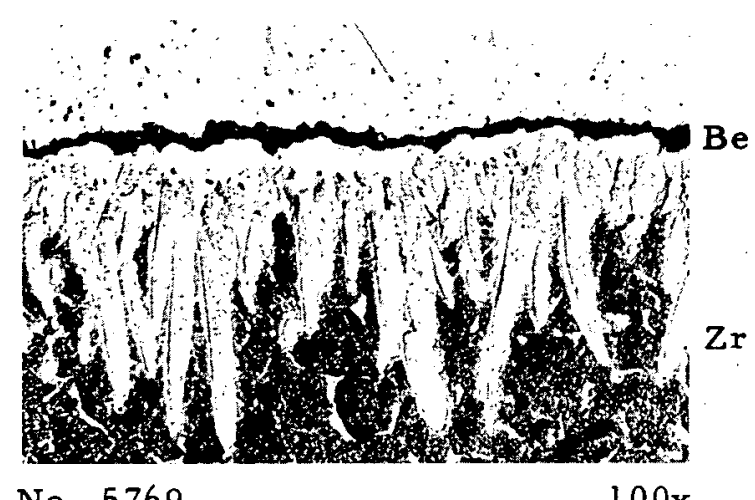

No. 5769

Figure 14

$\mathrm{Be}-\mathrm{Zr}$. Twenty-four days at $700^{\circ} \mathrm{C}$.

$\mathrm{Cb}$

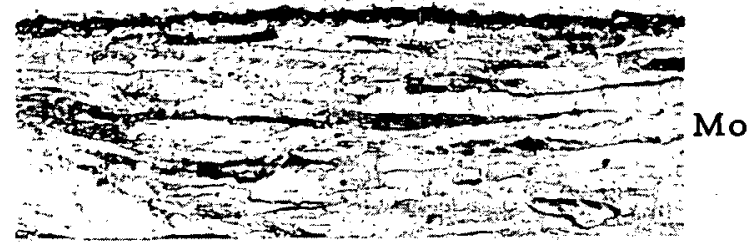

No. 5786

$500 x$

Figure 16

$\mathrm{Cb}-\mathrm{Mo}$. Twenty-four days at $700^{\circ} \mathrm{C}$.

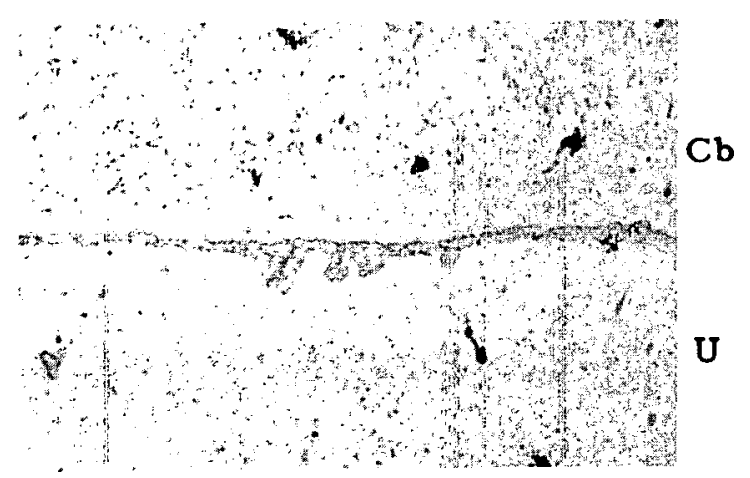

No. 5164

Figure 18

$\mathrm{Cb}-\mathrm{U}$. Twelve days at $700^{\circ} \mathrm{C}$.

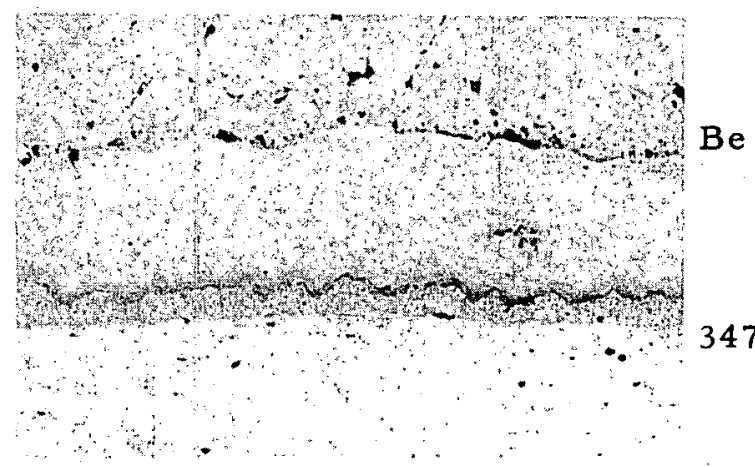

No. 5660

$250 x$

Figure 15

Be-347 Stainless Steel. Twelve days at $700^{\circ} \mathrm{C}$.

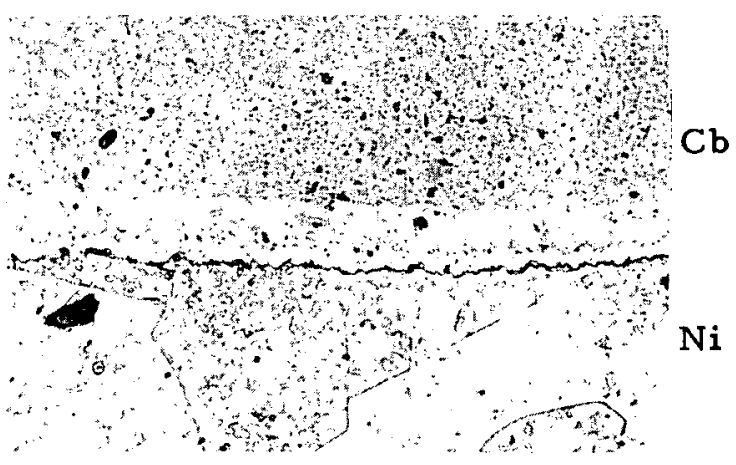

No. 5679

$250 x$

Figure 17

$\mathrm{Cb}-\mathrm{Zr}$. Twelve days at $700^{\circ} \mathrm{C}$.

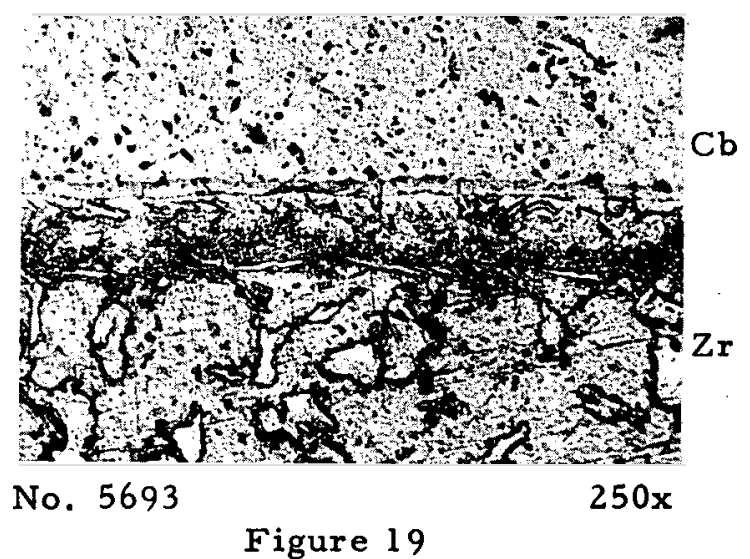

$\mathrm{Cb}-\mathrm{Zr}$. Twelve days at $700^{\circ} \mathrm{C}$. 


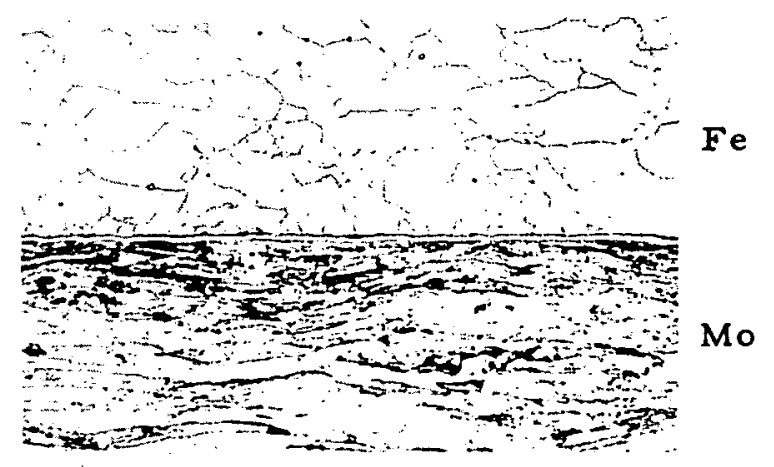

No. 5678

$250 \mathrm{x}$

Figure 20

Fe-Mo. Twelve days at $700^{\circ} \mathrm{C}$.

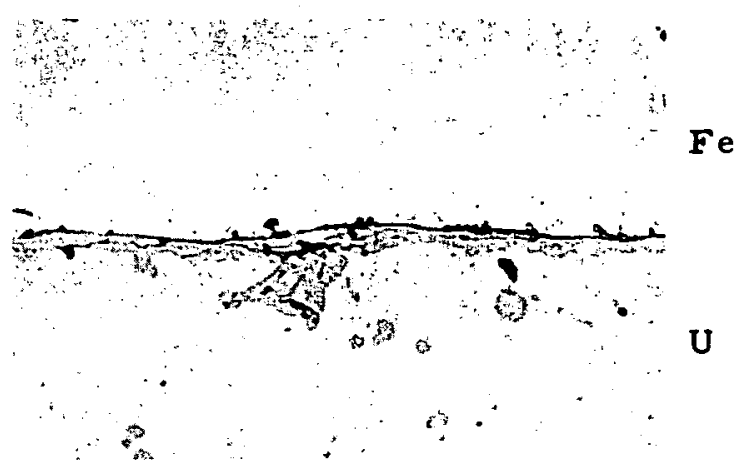

No. 5142

$500 x$

Figure 22

$\mathrm{Fe}-\mathrm{U}$. Twelve days at $700^{\circ} \mathrm{C}$.

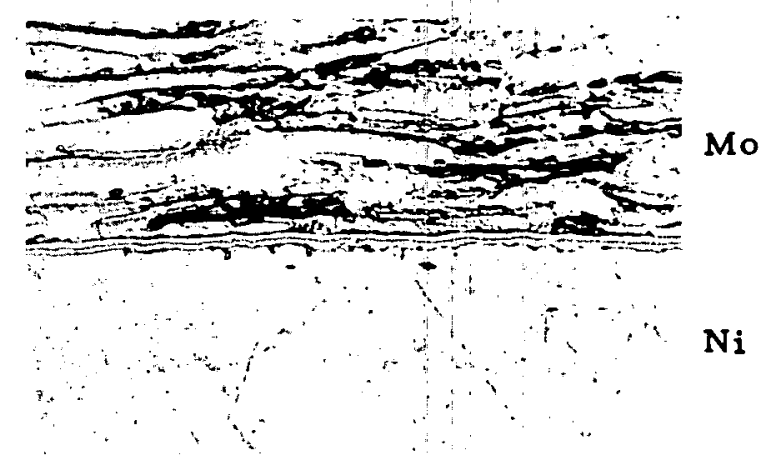

No. 5680

$500 x$

Figure 24

Mo-Ni. Twelve days at $700^{\circ} \mathrm{C}$.

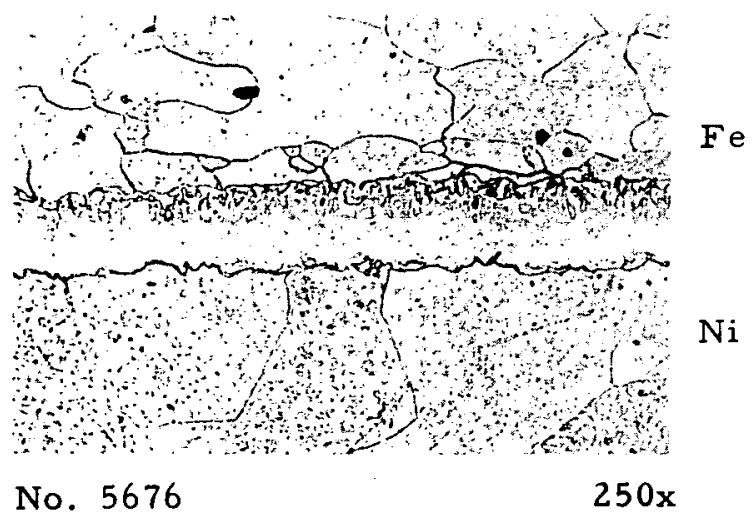

Figure 21

$\mathrm{Fe}-\mathrm{Ni}$. Twelve days at $700^{\circ} \mathrm{C}$.

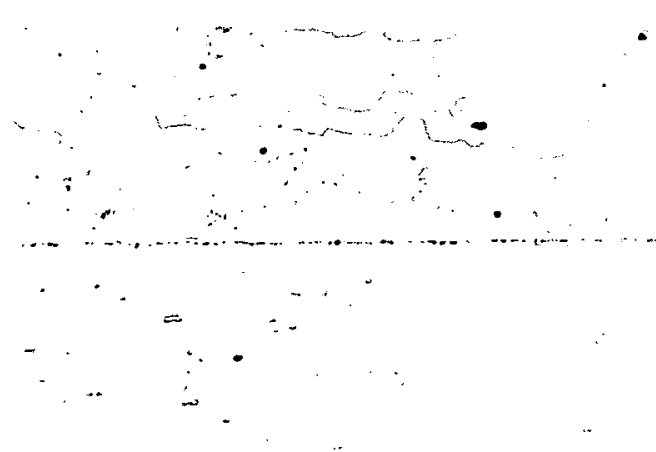

No. 5614

$250 x$

Figure 23

Fe-347 Stainless Steel. Six days at $700^{\circ} \mathrm{C}$.

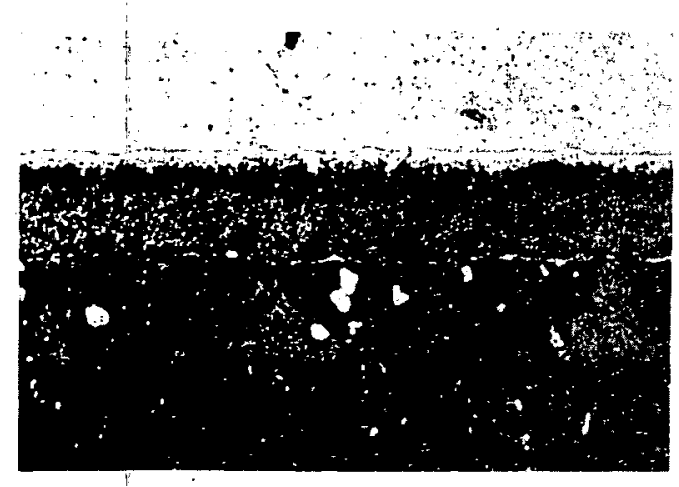

No. 5227

$250 x$

Figure 25

Mo-U. Eighteen days at $700^{\circ} \mathrm{C}$. 


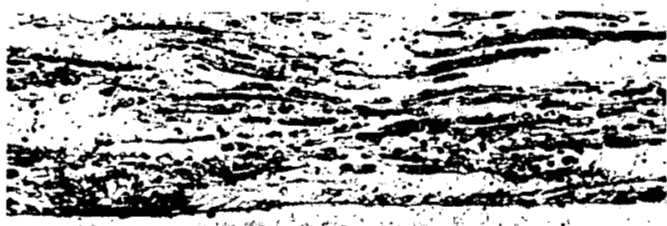

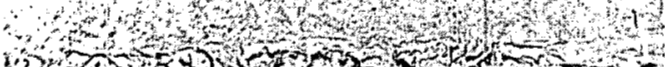

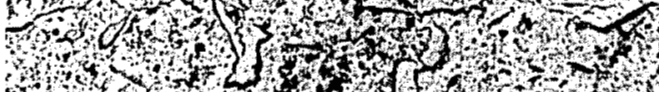

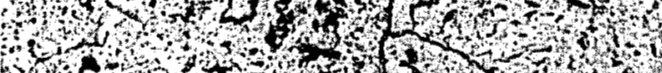
No. 5655

$250 x$ Figure 26

Mo-Zr. Twelve days at $700^{\circ} \mathrm{C}$.

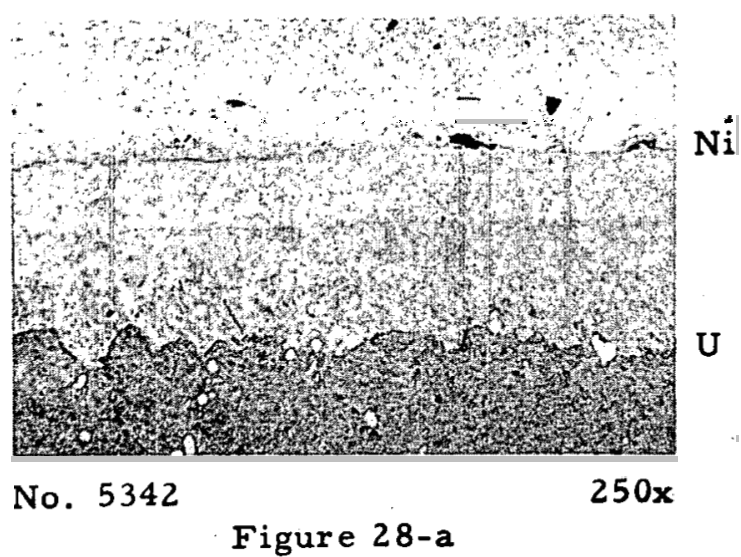

$\mathrm{Ni}, \mathrm{U}$. Six days at $700^{\circ} \mathrm{C}$.

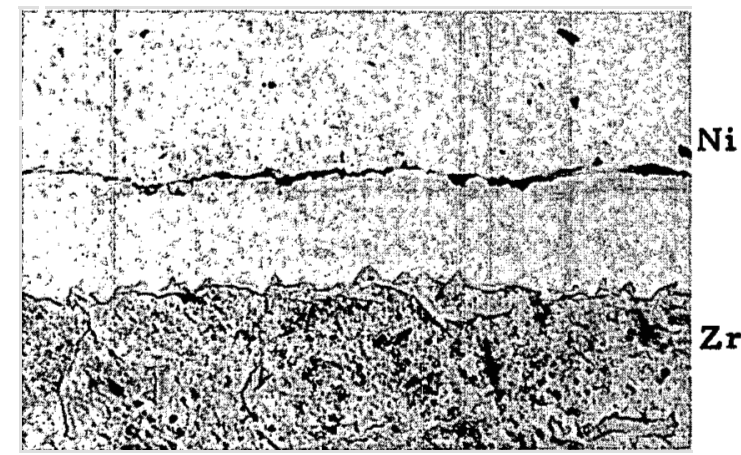

No. 5531

$250 x$

Figure 29

$\mathrm{Ni}-\mathrm{Zr}$. Twelve days at $700^{\circ} \mathrm{C}$.

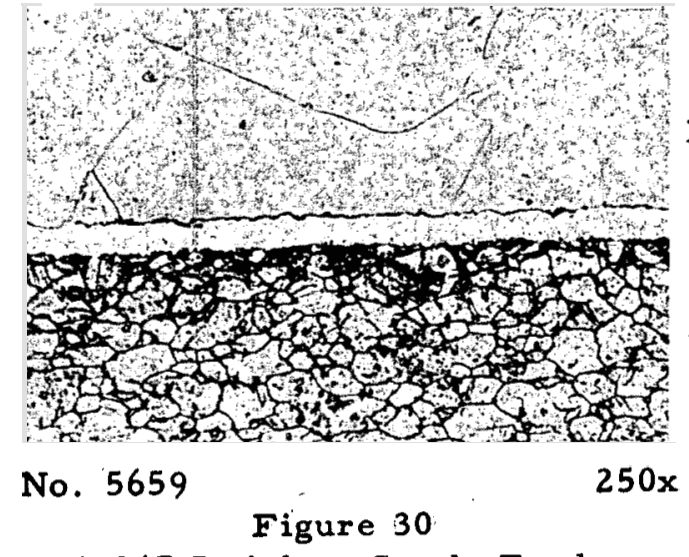

$\mathrm{Ni}-347$ Stainless Steel. Twelve days at $700^{\circ} \mathrm{C}$. 


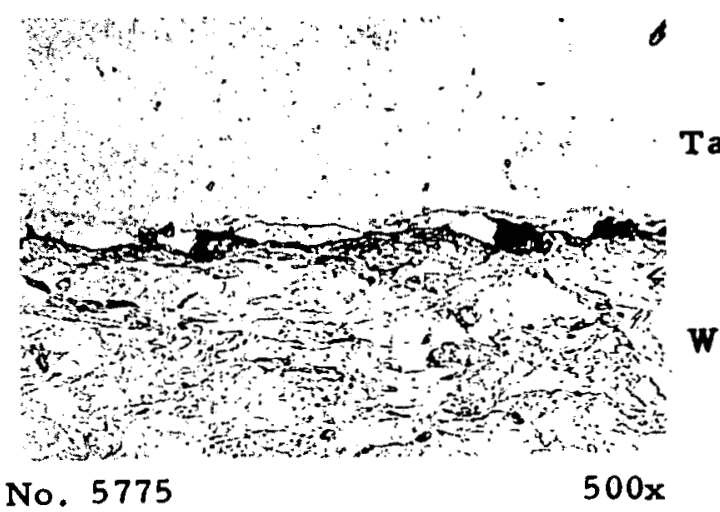

Figure 31

Ta-W. Twenty-four days at $700^{\circ} \mathrm{C}$.

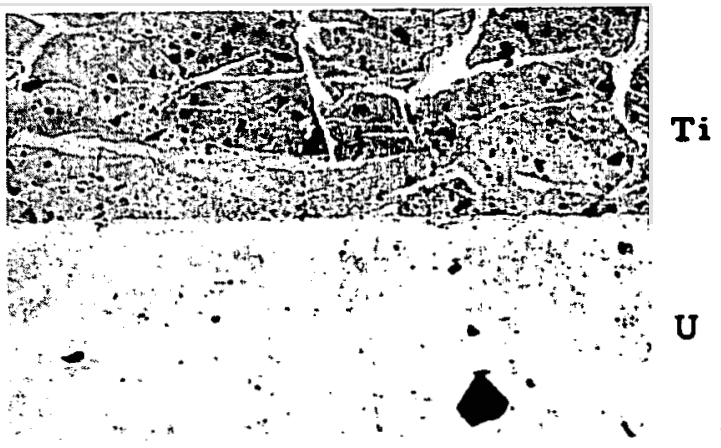

No. 6537

$500 x$

Figure 33

Ti-U. Twenty-four days at $500^{\circ} \mathrm{C}$.

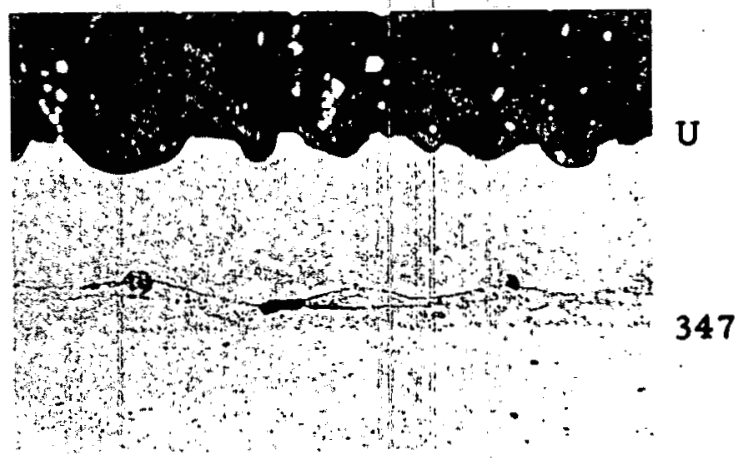

No. 5504

$250 x$

Figure 35

U-347 Stainless Steel. Six days at $700^{\circ} \mathrm{C}$.

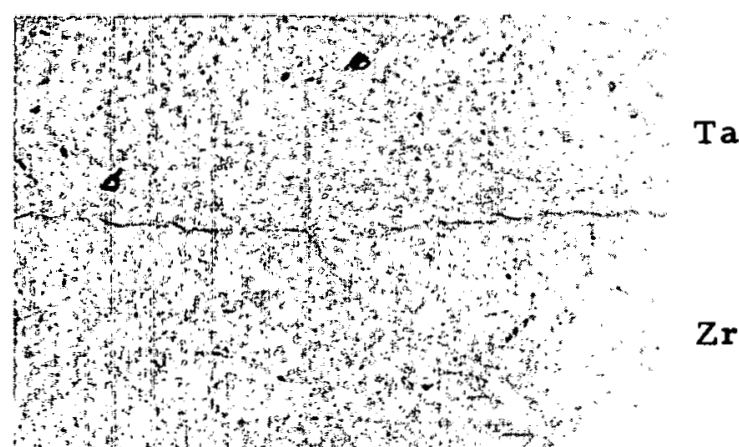

No. 5533

$500 x$

Figure 32

$\mathrm{Ta}-\mathrm{Zr}$. Twelve days at $700^{\circ} \mathrm{C}$.

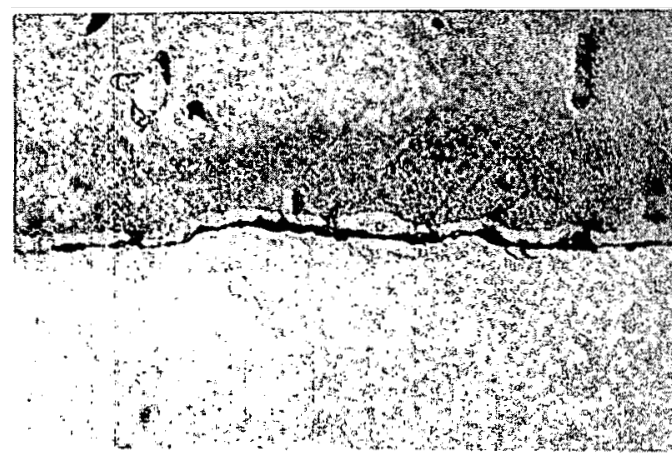

No. 5510

$1000 x$

Figure 34

$\mathrm{U}-\mathrm{Zr}$. Six days at $700^{\circ} \mathrm{C}$.

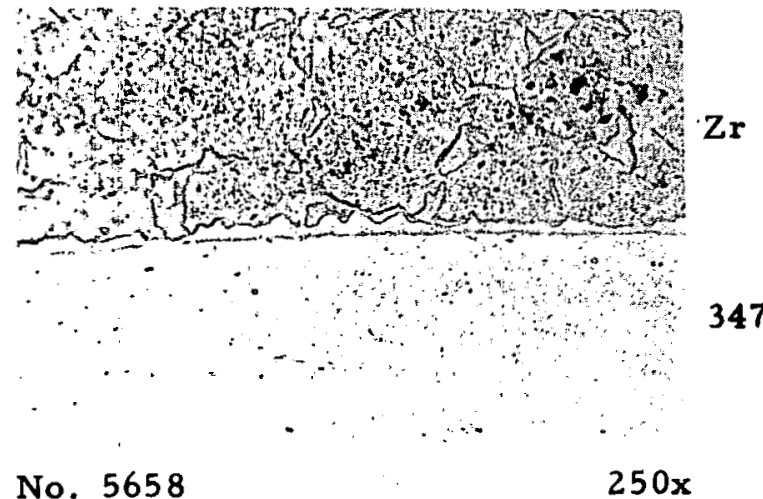

Figure 36

Zr-347 Stainless Steel. Twelve days at $700^{\circ} \mathrm{C}$. 
